\title{
REKONSTRUKSI MAQÂSHID AL-SYARI' AH DALAM PENGEMBANGAN METODOLOGI HUKUM ISLAM (Kajian Eksploratif Pemikiran Jasser Auda)
}

\author{
Ainol Yaqin \\ Institut Agama Islam Negeri (IAIN) Madura \\ Jl. Pahlawan KM. 04 Pamekasan, \\ E-mail: ainulfairus@gmail.com
}

\begin{abstract}
The Reconstruction of Maqâshid al-Syarîah in Development of Islamic Law Methodology (Explorative Study of Jasser Auda's Thoughts). Every Islamic law prescribed should be tucked with shariah objectives (maqâshid al-syarîah), which is expedient in the sense of broad sense that must be preserved or harm that should be rejected. Maqâshid al-syarîah is the result of the understanding, thought and cognition of scholars, both classical and contemporary scholars towards some syara' (Islamic law) so that it is not patent, stagnant and permanent. Jasser Auda endeavors to rearrange, reconstruct and integrate maqâshid al-syarî̀ah with all theories of Islamic legal methodology in order to respond to the complexity of the problems that engage Muslims. He conceptualized system theory to correct, analyze and rethink the methodology of Islamic law by making maqâshid al-syarîah its main base. This noble ijtihad is projected to present Islamic law with justice, equity, freedom, tolerance, compassion, civilization, brotherhood, human rights, humanity and environmental stewardship so that it can improve and build the main human resources of Islam in order to build a bright and advanced world civilization.
\end{abstract}

Keywords: maqâshid al-syarîah; progressive ijtihad; system theory; renewal (innovation); Islamic law.

\begin{abstract}
Abstrak: Rekonstruksi Maqâshid al-Syarîah dalam Pengembangan Metodologi Hukum Islam (Kajian Eksploratif Pemikiran Jasser Auda). Setiap hukum Islam yang disyariatkan mesti terselip tujuan-tujuan syariah (maqâshid al-syarîah), yakni maslahat dalam pengertian luas yang mesti dipelihara atau mudarat yang seharusnya ditolak. Maqâshid al-syarî̀ah merupakan hasil pemahaman, pemikiran dan kognisi para ulama, cendekiawan klasik maupun kontemporer terhadap sejumlah nas-nas syara' sehingga ia tidak bersifat paten, stagnan dan permanen. Tetapi, ia dapat berkembang, berubah dan bersifat dinamis seiring dengan pesatnya laju perkembangan dan kemajuan zaman. Jasser Auda berupaya ekstra/berijtihad untuk menata ulang, merekonstruksi dan mengintegralisasi maqâshid al-syarîaah dengan segala teori metodologi hukum Islam agar bisa merespons kompleksitas problem yang membelit umat Islam. la mengkonsepsi teori sistem guna mengoreksi, mengalisa dan memikirkan ulang metodologi hukum Islam dengan menjadikan maqâshid al-syarî̀ah sebagai basis utamanya. ljtihad mulia ini diproyeksikan untuk menghadirkan hukum Islam yang bernilai keadilan, kesetaraan, kebebasan, toleransi, kasih sayang, kemajuan berperadaban, persaudaraan, hak-hak asasi manusia, kemanusiaan, dan pemeliharaan lingkungan sehingga dapat meningkatkan dan membangun Sumber Daya Manusia (SDM) utamanya umat Islam supaya bisa membangun peradaban dunia yang cerah dan maju.
\end{abstract}

Kata kunci: maqâshid al-syarîah; ijtihad progresif; teori system; pembaruan; hukum Islam.

\section{Pendahuluan}

Hukum Islam disyariatkan untuk kemaslahatan manusia guna meraih kebahagiaan, kebaikan hidup di dunia dan akhirat. Setiap sesuatu atau perbuatan yang mendatangkan maslahat itu dibolehkan dan bahkan diwajibkan untuk dikerjakan. Maslahat dan manfaat itu bisa diketahui seketika atau di kemudian hari. Sebaliknya, segala sesuatu atau perbuatan yang berefek mudarat itu mesti dicegah, dilarang dan diharamkan. Mudarat tersebut dapat dirasakan dan diketahui seketika atau dalam waktu lama.

' Ibnu 'Âsyûr mendefinisikan maslahat dengan perbuatan yang mendatangkan kebaikan atau manfaat untuk waktu selamanya ataupun disebagian besar saja, yang menyentuh pada mayoritas maupun beberapa orang. Sedangkan mafsadat adalah kebalikan maslahat, yaitu suatu perbuatan yang mendatangkan kerusakan atau bahaya, baik berlangsung terus selamanya ataupun pada sebagian besar saja, dirasakan oleh 
Hukum Islam juga menjunjung nilai-nilai mulia dan berdimensi universal, keadilan, kesetaraan, kebebasan, toleransi, kasih sayang, kemajuan berperadaban, persaudaraan, hak-hak asasi manusia, kemanusiaan, dan pemeliharaan lingkungan. ${ }^{2}$ Nilai-nilai ini berdasarkan kajian terhadap sejumlah nas-nas Alquran dan sunah.

mayoritas orang maupun beberapa orang". Muhammad alThâhir Ibn 'Âsyûr, Maqâshid al-Syarî’ah al-Islâmiyah, (Yordan: Dâr al-Nafầis, 2001), Cet.ke-2, h. 278-279. Para ulama usul fikih klasik, seperti 'Abdurrahmân al-îjî, al-Syâthibî, al-Ghazâlî, dan 'Izz al-dîn Ibn 'Abdusalâm memberi pengertian maslahat dengan beragam redaksi, tetapi mengarah pada substansi yang serupa. Abdurrahmân al-Îjî mendefinisikan maslahat dengan "kezelatan dan perantaranya, sedangkan mafsadat adalah penyakit dan perantaranya, baik bersangkut paut dengan jiwa, badan, dunia dan akhirat. Abdurrahmân alîjî, Syarh Mukhtashar al-Muntahâ al-Ushûlî, (Beirut: Dâr alKutub al-Ilmiyah, 1983), Juz II, h. 329. Begitu pula, al-Syâthibî menyatakan maslahat adalah perbuatan yang mendatangkan kebaikan atau manfaat, baik berlaku secara umum ataupun khusus, yang sesuai dengan ketetapan jiwa dalam rangka pemeliharaan kehidupan manusia. Abû Ishâq al-Syâthibî, alMuwâfaqât fî Ushûl al-Syarî’ah, (Beirut: Dâr al-Ma'rifat, 1996), Juz II, h. 339. Al-Ghazâlî berujar maslahat adalah sebuah ibarat yang pada intinya tentang perbuatan yang mendatang manfaat atau menolak mudarat. Yang kami maksudkan dengan maslahat bukanlah ini, karena mendatangkan manfaat dan menolak mudarat merupakan tujuan dari makhluk. Kebaikan makhluk dalam memperoleh tujuan-tujuannya. Yang kami maksud dengan maslahat adalah menjaga tujuan syara'. Tujuan syara' untuk makhluk ada lima, yaitu perlindungan agama, jiwa, akal, keturunan dan harta mereka. Maka setiap perbuatan yang mengandung perlindungan lima dasar ini disebut dengan maslahat. Sebaliknya, setiap perbuatan yang meniadakan kelima dasar tersebut tergolong mafsadat dan penolakan atasnya dinilai maslahat. Abû Hâmid Muhammad al-Ghazâlî, al-Mustashfâ min 'Ilmi al-Ushûl, (Beirut: Mu'assasah al-Risâlah, 1998), Jilid I, h. 414. 'Izz al-dîn Ibn 'Abdussalâm mengutarakan maslahat ada empat macam: kelezatan dan sebab-sebabnya, kegembiraan dan sebab-sebabnya. Sedangkan mafsadat ada empat macam: penyakit dan sebab-sebabnya, kesukaran dan sebab-sebabnya. Maslahat dan mafsadat dengan segenap macamnya, ada yang berkaitan dengan masalah duniawi dan juga ukhrawi. Ibn 'Abdussalâm, Qawâ'id al-Ahkâm fî Mashâlih al-Ânâm, (Damasykus: Dâr al-Qalam, t.th), Juz I, h. 15.

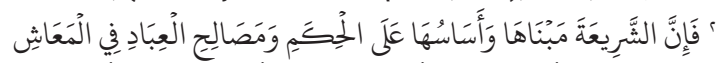

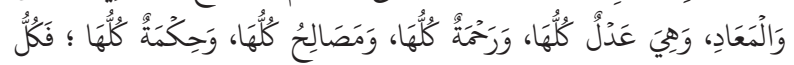

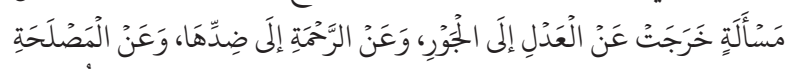

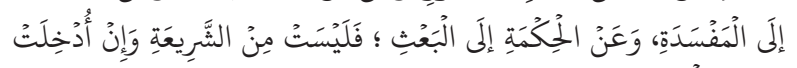
فِيَهَا بِالتَُّْوِِلِ.

Ibn Qayyim al-Jawziyah menyatakan prinsip atau dasar syariah adalah kebijaksaan dan kemaslahatan hidup manusia di dunia dan akhirat. Keseluruhan syariat bernuansa keadilan, kasih sayang, kebijaksanaan dan kemaslahatan. Maka setiap aturan yang mengandung ketidakadilan, kezaaliman, mafsadat atau tidak gunanya maka peraturan tersebut bukan termasuk syariat, sekalipun dimanipulasi untuk dimasukkan sebagai bagian dari syariat dengan berbagai interpretasi. Ibn Qayyim al-Jawziyah, A'lâm al-Muwaqqi'în 'an Rabbil'âlamîn, (Beirut: Dâr al-Fikr, 1977), Jilid III, h. 149.
Namun, nilai-nilai mulia itu seolah-olah berada dalam dunia ide, sebatas impian, tidak menyentuh dalam tatanan riil umat Islam. Realitanya, sejumlah negara yang mayoritas berpenduduk muslim berada dalam level rendah ketimbang negara maju dari berbagai segi, baik pendidikan, politik, ekonomi, ilmu pengetahuan dan teknologi. Selain itu, kondisi umat Islam berbanding terbalik dengan nilai-nilai luhur itu. Negara yang berpenduduk mayoritas muslim hidup dalam ketegangan intoleransi, mengekang kebebasan, minim penegakan keadilan, merebaknya korupsi, rendahnya kualitas pendidikan, diskriminasi, marak pelanggaran pada hak-hak asasi manusia, ketidakadilan gender, kurang peduli kebersihan dan pemeliharaan lingkungan. ${ }^{3}$ Oleh sebab itu, dibutuhkan terobosan dan paradigma baru yang progresif guna mengeluarkan umat Islam dari problem yang kompleks ini.

Tulisan ini akan menjabarkan dan menganalisa metodologi hukum Islam dengan teori sistem berbasis maqâshid al-syarîah. Ulasan-ulasan yang akan dibahas adalah penelusuran akar teori sistem guna mengetahui urgensinya dalam membuat pisau analisis terhadap pengembangan metodologi hukum Islam, bagaimana konsep maqâshid alsyarîah perspektif Jasser Auda, bagaimana pendekatan sistem terhadap metodologi hukum Islam, dan bagaimana interelasi sejumlah dalâlah linguistik dengan maqâshid.

\section{Kegelisahan Intelektual Jasser Auda}

Sejak tragedi serangan super dahsyat yang menghancurleburkan World Trade Center (WTC), 11 September 2001 lalu, yang berakibat menelan banyak korban jiwa membuat para cendekiawan muslim, baik dunia Timur maupun Barat berpikir keras mengapa hal itu bisa terjadi. Apalagi sulit diterima akal sehat tragedi itu dilakukan oleh se-

${ }^{3}$ Laporan Program Pembangunan PBB (UN Development Report) menginformasikan sejumlah negara yang berpenduduk mayoritas muslim berada di tingkat posisi lebih rendah dibandingkan negara maju dalam hal Indeks Pembangunan Manusia (IPM). Daftar IPM yang bertengger di urutan bawah meliputi Yaman, Nigeria, Mauritania, Djibouti, Gambia, Senegal, Guinea, Pantai Gading, Mali dan Niger (secara kolektif mewakili sekitar 10\% umat Islam). Jasser Auda, Maqâshid al-Syarî’ah kafalsafah littasyrî’ al-islâmî ru yah manzhûmiyah, diterjemahkan ke dalam bahasa arab oleh 'Abdullathîf al-Khayyath, (Jordania: al-Ma'had al-‘Âlamî li al-Fikr al-Islâmî, 2012), h. 36. 
bagian umat yang mengatasnamakan diri mereka beragama Islam. Peristiwa yang meremukkan nilainilai kemanusiaan itu tidaklah dapat dibenarkan dengan dalih apa pun. Semua agama dan lebih-lebih agama Islam sebagai penyempurna agama-agama sebelumnya tidak mengajarkan kekerasan, teror, pengrusakan, penghacuran, pemusnahan dan sebagainya. Sebaliknya, setiap agama menyerukan pada kedamaiaan, kerukunan, cinta kasih, toleransi, tolong-menolong dan nilainilai luhur lainnya.

Peristiwa mengejutkan berupa peledakan bom pada 7 Juli 2005 yang menewaskan 52 orang dan sejumlah tragedi nir-humanisme di London, Inggris membuat Jasser Auda ${ }^{4}$ berpikir dan bertanya-tanya; apa yang terjadi dengan umat Islam, apa kekeliruan-kekeliruan dalam Islam. Kegelisahan intelektualnya ia tuangkan dalam karya monumentalnya yang berjudul "Maqasid

${ }^{4}$ Dia adalah tokoh intelektual muslim kontemporer berkebangsaan Mesir, multidisipliner dan pakar maqâshid alsyarî'ah yang cukup lama tinggal di Barat. Semangat intelektualnya sangat kuat menyala sehingga membuat ia malang melintang dari satu negeri ke negeri lain untuk menuntut, mengembangkan dan meningkatkan ilmu pengetahuan. Gelar Ph.D pertama diperoleh dari diperoleh dari Universitas Waterloo, Kanada, dengan kajian analisis sistem tahun 2006. Sedang gelar Ph.D kedua diraih dari University of Wales, Inggris, pada konsentrasi Filsafat Hukum Islam tahun 2008. Master Fikih diperoleh dari Universitas Islam Amerika, Michigan, pada tujuan hukum Islamta hun 2004. Gelar BA diperoleh dari Jurusan Islamic Studies pada Islamic American University, USA, tahun 2001 dan gelar BSc diperoleh dari Engineering Cairo University, Egypt Course Av. Tahun 1988. Sedangkan ilmu Alquran dan ilmuilmu keislaman ia dapatkan di Masjid Al- Azhar, Kairo. Aktivitas keseharian Auda sangat memperkuat, menunjang dalam perkembangan dan peningkatan nalar intelektualnya. Pakar maqâshid al-syarî’ah itu perintis sekaligus direktur Maqâshid Research Center dalam bidang Filsafat Hukum Islam di London, Inggris. la juga punya andil besar sebagai pendiri dan anggota di sejumlah organisasi ternama di beberapa negara, yaitu anggota pendiri International Union of Muslim Scholar yang berpusat di Dublin; anggota Academic Board of the International Institute of Islamic Thougth di London, Inggris; anggota International Institute of Advanced Systems Research (IIAS) di Kanada; anggota Board of Trustees of the Global Civilizations Study Centre (GCSC) di Inggris dan sebagainya. Tokoh intelektual muslim itu menjadi dosen tamu di sejumlah universitas dalam beberapa negara; fakultas hukum Universitas Alexandria, Mesir, Islamic of Toronto, Kanada, Akademi Fikih Islam, India dan di sejumlah negara lainnya. Ide-ide briliannya dituangkan dalam beberapa buku, ratusan tulisan dalam bentuk jurnal cetak maupun jurnal online, tulisan media, dialog ilmiah yang tersebar ke seluruh penjuru dunia. M. Amin Abdullah, "Epistemologi Keilmuan Kalam dan fikih Dalam Merespon Perubahan di Era Negara-Bangsa dan Globalisasi; Pemikiran Filsafat Keilmuan Agama Islam Jasser Auda" dalam Jurnal al-Syir'ah, Vol. XIV No. 2 Juli - Desember 2012. h. 127.
Syariah as Philosophy of Islamic Law: A Systems Approach", ia berkisah:

Saya menulis hal ini setelah saya mengemudi mobil pagi ini melalui Kota London, Inggris menuju kantor saya. Itu seharusnya menjadi pengalaman menyenangkan, karena cuaca bulan Juli langit sangat cerah pada hari ini. Akan tetapi, sayang sekali mengemudi pagi ini menjadi pengalaman pahit yang menegangkan, karena kota ini dan bahkan seluruh negeri berada pada tingkat siaga satu. Polisi menginformasikan kepada kami bahwa telah terjadi serangan teroris. Hal ini menunjukkan teroris menjadi ancaman nyata! Jadi, kondisi semacam ini, sebagaimana penduduk London, saya juga takut melewati kota London, dan selalu waspada mengamati setiap perilaku yang mencurigakan. Namun, saya makin gusar dengan pemberitaan di London dalam beberapa hari terakhir, karena apa yang saya sebut sebagai aksi kriminal (lebih benar daripada aksi terorisme)ini dilakukan atas nama hukum Islam, sebagaimana klaim beberapa pelakunya. Ketika saya mendengar perkataan itu, saya dengan kondisi marah berseru: hukum Islam? Apa hukum Islam? Apakah hukum Islam membolehkan membunuh manusia tanpa pandang bulu di kota-kota yang damai? Dimana "kebijaksanaan dan harmonisasi antar manusia" yang diketahui setiap Muslim sebagai bagian yang melekat pada hukum Islam?.5

Selain kegelisahan di atas, Jasser Auda juga diherankan dengan laporan tahunan dari United Nation Development Programme (UNDP) tentang indeks pembangunan manusia (Human Development Index) menunjukkan bahwa negaranegara yang dihuni mayoritas penduduk muslim berada pada level rendah dalam beberapa faktor, pendidikan, kesehatan, pendapatan ekonomi, pemberdayaan perempuan dan standar hidup. Demikian juga sejumlah negara Arab yang memiliki rata-rata pendapatan perkapita sangat tinggi berbanding terbalik dalam hal keadilan, pemberdayaan perempuan, partisipasi politik dan kesetaraan gender. Berbagai pelanggaran hak asasi manusia dan korupsi mewabah di negara-negara

5 Jasser Auda, Maqasid Shariah as Philosophy of Islamic Law: A Systems Approach, dialihbahasa ke dalam bahasa arab oleh 'Abdullathîf al-Khayyath dengan judul Maqâshid al-Syarî'ah kafalsafah littasyrî’ al-islâmî ru’yah manzhûmiyah., h. 19. 
berpenduduk mayoritas muslim. Problem lainnya yang melilit penduduk minoritas muslim terkait kewarganegaraan, mu'amalah, politik yang hidup berdampingan dengan mayoritas di negara non muslim. Realita tersebut menjadi problem serius yang mesti ditangani, diatasi dan dicarikan solusinya.

Sejumlah fenomena di atas pada dasarnya jauh dari nilai-nilai Islam yang adi luhung. Jasser Auda menyatakan:

"Hukum Islam bernilai humanis, responsif, progresif dan menjunjung keadilan, produktivitas, pembangunan sumber daya manusia dan sumber daya alam, spiritual, kebersihan, persatuan, kasih sayang dan demokratis. Sayangnya, nilai-nilai luhur itu minim dijumpai dalam tataran realitas di komunitas muslim manapun. Sebab itu, pertanyaan besar saya adalah di manakah hukum Islam? dan bagaimanakah hukum Islam mengatasi dan memecahkan problema riil ini?". ${ }^{6}$

\section{Melacak Akar Geneologi Teori Sistem}

Teori dan filsafat sistem muncul pada paruh kedua abad ke-20 M sebagai anti-tesis terhadap filsafat modern dan postmodern. Filsafat sistem menolak pandangan 'reduksionis (الاختزالية)' kalangan modernis yang menganggap bahwa seluruh pengalaman manusia bisa dianalisis dengan logika sebab-akibat. Di sisi lain, filsafat sistem juga menolak irasionalitas (اللا عقلانية) dan dekontruksi (النفكيكية) yang digaungkan kelompok postmodern yang cenderung sebagai meta-narasi (الخرافات العظىى). Kedua tesis tersebut ditolak oleh filsafat sistem dengan argumen bahwa alam semesta bukanlah sebuah mesin yang bergerak serba pasti (sebagaimana pandangan kalangan modernis), atau ciptaan yang tidak dapat diketahui sama sekali (sebagaimana pandangan postmodernis). Kompleksitas alam semesta tidak bisa dijelaskan hanya melalui sebab-akibat saja maupun irasionalitas non-logosentris. Problem dunia kontemporer tidak dapat hanya diselesaikan baik oleh perkembangan teknologi yang melesat maju maupun beberapa bentuk nihilisme (العدمية).7

Adapun pendekatan sistem adalah sebuah pendekatan yang holistik, yang entitas apa pun

\footnotetext{
${ }^{6}$ Jasser Auda, Maqâshid al-Syarî’ah..., h. 20-21.

7 Jasser Auda, Maqâshid al-Syarî'ah..., h. 69.
}

dipandang sebagai satu kesatuan sistem yang terdiri dari sejumlah subsistem. Ada sejumlah fitur sistem yang dapat mewarnai analisis sebuah sistem terhadap komponen-komponen subsistemnya, dan juga menentukan bagaimana subsistem-subsistem ini berinteraksi satu sama lain maupun berinteraksi dengan lingkungan luar. Sementara itu, Jasser Audah mendefinisikan sistem adalah suatu disiplin independen baru yang meliputi sejumlah subdisiplin ilmu, di mana teori sistem dan analisis sistematis yang relevan dengan tatakerja ini. Teori sistem adalah pendekatan filosofis yang 'anti-modernisme' yang mengkritik modernism dengan cara yang berbeda dengan teori postmodern. Konsep-konsep dari teori sistem, seperti keutuhan, multidimensi, keterbukaan dan berorientasi pada maqâshid, akan dimanfaatkan dalam pengembangan metodologi analisis. Berhubungan dengan pendekatan sistem adalah sains kognitif (cognitive science), bagian konsep-konsep dari sains kognitif akan digunakan untuk mengembangkan konsep dasar teori hukum Islam, seperti klasifikasi/kategorisasi dan sifat kognitif (cognitive nature) hukum. Konsep kultur kognitif (cognitive culture) juga akan digunakan untuk mengembangkan konsep 'urf dalam teori hukum Islam. Lebih lanjut, ia menegaskan penelitian multidisipliner sangat urgen dengan tujuan mengembangkan teori usul fikih melalui pendekatan sistem. Bagi Jasser Auda, aplikasi saat ini (lebih tepatnya, mis-aplikasi) dalam hukum Islam adalah reduksionis daripada holistik اختزالي) (حرفي) لاخئ) لا شمولي (حرفي لا أخلاقي), literal daripada moral satu أحادي البعد لا متعدد) dimensi daripada multideimensi (الأبعاد), dekontruksionis daripada rekontruksinonis (تفكيكي لا تركيبي), kausal daripada berorientasi kepada teleologis (سبية لا مقاصدية). Hal tersebut mengakibatkan ada kelemahan konsiderasi dan fungsionalitas keseluruhan maqâshid dan prinsipprinsip pokok hukum Islam sebagai suatu kesatuan. Selain itu, diperparah dengan klaim-klaim berlebihan mengenai 'kepastian rasional' atau 'irasionalitas'. Begitu pula klaim berlebihan itu meliputi 'konsensus yang tidak dapat ditolak' atau 'historisitas teks suci'. Kesemuanya ini memperpuruk kelemahan spiritual (ضعف الروحانية), intoleransi (عدم السماحة), ideolog kekerasan (الايديولوجية العنيفة), kebebasan yang dibelenggu (الحرية الضائعة), dan rezim otoriter (النظم السياسية الاستبدادية ). Metodologi dominan 
umumnya menolak belajar dari filsafat-filsafat lain yang tidak bersumber dari tradisi Islam atau sebaliknya, secara keseluruhan mengadopsi filsafatfilsafat lain mesti bertolakbelakang dengan akidah dasar Islam. ${ }^{8}$

Teori sistem mencanangkan jalan tengah antara aliran realis (النمطي الواقي) dengan aliran nominal (النمطي الاسي) dalam memecahkan korelasi antara sistem dengan dunia realita. Menurut aliran realis, realitas fisik adalah obyektif dan ekternal bagi kesadaran individual. Implikasinya, pengalaman manusia dengan sistem merepresentasikan kebenaran dunia nyata. Sebaliknya, aliran nominal beranggapan bahwa realitas itu bersifat subyektif dan merupakan sebuah kesadaran mental individual. Implikasinya, adanya dualitas antara realitas dan konsepsinya, di mana sistem hanya berada dalam pikiran kita dan tidak berkaitan dengan dunia fisik. Filsafat sistem menegaskan kognisi mental kita terhadap dunia luar berkorelasi dengan apa yang ada di sana. Sebuah sistem tidak mesti identik dengan benda-benda yang ada di dunia nyata, melainkan sistem adalah sebuah cara mengorganisasi pikiran kita tentang dunia nyata. ${ }^{9}$ Karena teori sistem merupakan proses untuk mengetahui dunia nyata, maka Jasser Auda menjadikan teori sistem sebagai sebuah pendekatan dalam mengembangkan epistemologi hukum Islam.

Untuk mengkonsepsi dan mengimplikasikan teori sistem sebagai sebuah pendekatan dan analisis, Jasser Auda sangat serius menelaah, mengkaji, mengalisa sejumlah buku induk yang ditulis para pakar yang berkompeten. Di antara tokoh utama teori sistem yang dijadikan rujukan adalah Bertalanffy (Bapak Teori Sistem), Katz dan Kahn, Ackoff, Churchman, Boulding, Bowler, Maturana dan Varela, Luhmann, Gharajedaghi, Hitchins, Koestler, Weaver, Simon, Jordan, Beer, dan Skyttner. ${ }^{10}$

\footnotetext{
${ }^{8}$ Jasser Auda, Maqâshid al-Syarî'ah..., h. 26-27.

9 Jasser Auda, Maqâshid al-Syarî'ah..., h. 71-72.

${ }^{10}$ Bertalanffy mengidentifikasi fitur-fitur atau karakterisktik sistem pada sepuluh bagian, ringkasnya; holistik, memiliki tujuan, saling mempengaruhi, masukan dan keluaran, transformasi, regulasi, hierarki, diferensiasi, ekuifinalitas dan multifinalitas, entropi. Katz dan Kahn merumuskan sistem terbuka pada sejumlah fitur; penyerapan energi, masukan informasi, masukan, keluaran, siklus peristiwa, entropi negative, proses koding, ekuilibrium, diferensiasi, integrasi dan ekuifinalitas. Churchman
}

\section{Pengembangan Sumber Daya Manusia (SDM) sebagai Maqâshid al-Syarî̀ah}

Pada cendekiawan kontemporer berupaya merevitalisasi dan mereformulasi maqâshid alsyarîah agar bisa relevan dan responsif dalam memecahkan problem umat yang semakin kompleks. Mereka secara langsung menelaah, mengkaji dan melacak nas-nas syara' guna menyusun kerangka maqâshid al- syarîa hehingga bisa mencover kemaslahatan yang mengisi ruang zaman. Perubahan ini sangat penting, karena perubahan zaman merupakan sebuah keniscayaan, sedangkan nas-nas sebagai acuan istinbâth hukum jumlahnya terbatas. Diantara mereka yang berijtihad dalam merefomulasi dan merekonstruksi maqâshid al-syarî’ah sebagai berikut:

Rasyîd Ridhâ (w. 1354 H/1935 M) mengkaji Alquran untuk menyelami maqâshid al-syarîaah sehingga ia menyimpulkan bahwa maqâshid mencakup; perbaikan sendi-sendi agama ( $ح$ اصل (آركان الدين, penyebaran perkara-perkara kenabian, Islam agama fitrah (الاسلام دين الفطرة), akal logika (العقل), ilmu pengetahuan (العلمة), kebijaksanaan (الحكمة), berpikir logis (البرهان), kebebasan (الحلة), kemerdekaan (الاستقلال), reformasi sosial, ekonomi, politik (الاصلاح الاجتماعي الاقتصادي السياسي) dan hakhak wanita (حقوق النساء)."11

Begitu pula, Ibnu 'Âsyûr (w. 1325 H/1907 M) berlandaskan kajiannya atas Alquran ia merumuskan maqâshid umum hukum Islam adalah memelihara keteraturan umat (حفظ نظام الأمة) (المرية), kesetaraan (المساواة), kebebasan (الحرية), toleransi (السماحة), global (العالمية) dan fitrah (الفطرة). Ibnu 'Âsyûr menandaskan mutiara hikmah toleransi dalam syariat Islam adalah dijadikannya syariat Islam seirama dengan fitrah yang terhunjam dalam jiwa manusia sehingga dengan mudah bisa diterima. Fitrah manusia menjauhkan diri dari tindakan ektrimis, kekerasan dan pelampauan batas, sebab itulah yang selaras dengan prinsip

\footnotetext{
mengidentifikasi fitur-fitur sistem berikut; berorientasi maksud, memiliki bagian-bagian yang bermanfaat pada dirinya sendiri, performa dapat ditentukan, memilik pemakai, tertanam di suatu lingkungan dan sebagainya. Boulding menyatakan bahwa ketersusunan, keteraturan dan ketidak semrawutan secara alami labih baik dibandingkan kurang tersusun, ketidak-teraturan dan kesemrawutan. Penjelasan lengkapnya baca, Jasser Auda, Maqâshid al-Syarî'ah..., h. 81-92.

${ }^{11}$ Jasser Auda, Maqâshid al-Syarî’ah..., h. 36.
} 
syariat Islam yang berdimensi universal dan eternal. Karenanya, Islam mengedepankan kemudahan dalam mengamalkan syariatnya serta menafikan perkara yang menyulitkan dan menyusahkan. AlMusâwah (egaliter), dalam arti setiap umat Islam berposisi sederajat/sama di hadapan hukum Islam. Tiada perbedaan secuilpun di muka hukum Islam antara orang yang kuat, lemah, mulia, hina dan sebagainya. Hal ini bertumpu pada asas yang mendasar, yaitu Islamsebagai agama fitrah. Prinsip al-musâwah dalam syariah Islam bertitik pangkal pada persamaan umat manusia dalam hal penciptaan. Dari sisi bashariyah-nya manusia adalah sama, kesemuanya berasal dari Nabi Âdam as. Mereka sama-sama memiliki hak hidup di muka bumi selaras dengan fitrah-Nya, tidak ada perbedaan lantaran berlainan warna kulit, bentuk rupa atau tempat tinggal. Karena itulah, prinsip persamaan ini meniscayakan pemberlakuan sama dalam dasar-dasar syara'. Sementara kebebasan tercermin dalam ajaran Alquran yang menekankan tiada paksaan dalam penganutan agama. ${ }^{12}$

Muhammad al-Ghazâlî (w. 1416 H/1996 M) memasukkan keadilan (العدالة) dan kebebasan (الحرية) pada tingkatan dharûriyyât. ${ }^{33}$ Demikian halnya, Yûsuf al-Qardhâwî (I. 1345 H/1926 M) setelah menelaah Alquran sehingga merumuskan maqâshid umum berikut ini: merawat akidahakidah yang benar (تصحيح العقائد), memelihara harkat dan hak-hak asasi manusia (الانحرير كرامة), تقدة (الانسان و حقوقه (الدعرة (ال) kepada Allah Swt. (الدعوة الى عبادة الله النه (تركية), menyucikan

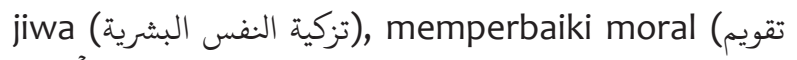

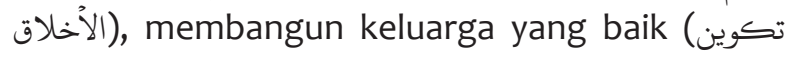
تالاسرة الصالحة (الخلاف), memperlakukan wanita dengan adil (انصاف المرأة), membangun umat yang berkualitas dan menyeru pada dunia

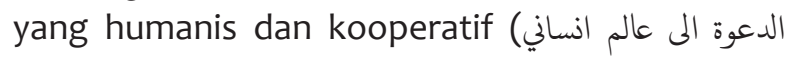
متعاون).14 Sementara itu, Thaha Jâbir al-'Alwanî (I. $1354 \mathrm{H} / 1935 \mathrm{M}$ ) sesudah mengkaji Alquran sehingga ia menemukan maqâshid al-syarîah tertinggi adalah tawhîd/mengesakan Allah swt. (التوحيد), membersihkan jiwa (التزكية) dan mengembangkan

${ }^{12}$ Muhammad Thâhir Ibn 'Âsyûr, Maqâshid al-Syarî’ah alIslâmiyyah, (Yordan: Dâr al-Nafầis, 2001), h. 252-330.

${ }^{13}$ Jamâluddîn 'Athiyyah, Nahwa Taf'îl Maqâshid al-Syarî’ah, (Damaskus: Dâr al-Fikr, 2001), h. 98.

14 Yûsuf al-Qardhâwî, Kaifa Nata'âmal ma'a al-Qur'ân al'Adhîm, (Kairo: Dâr al-Shurûq, 1999), h. 73-123.

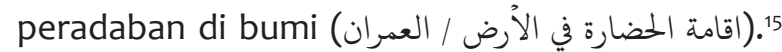

Jasser Auda menilai sangat penting memasukkan pengembangan atau pembangunan Sumber Daya Manusia (الننمية البشرية) dalam maslahat umum yang menjadi salah satu maqâshid al-syarîah yang direalisasikan dalam hukum Islam. Hal ini sangat mungkin direalisasikan dan bisa diukur dengan mengacu pada target-target pengembangan SDM menurut Perserikatan Bangsa-Bangsa (PBB) (الامم المتحدة) dan dikaitkan dengan maqâshid yang lainnya. Karena, fakta dan data menginformasikan negara-negara berpenduduk mayoritas muslim tingkat Indeks Pembangunan Manusianya (IPM) lebih rendah ketimbang negara maju. Bagi Jasser Auda, dinilai penting melihat laporan pembangunan SDM versi PBB karena berlandaskan dari 200 indikator, diantaranya mengukur partisipasi politik, kemampuan baca-tulis, tingkat pengembangan pendidikan, harapan hidup, terpenuhinya air bersih, tingkat pengangguran, standar hidup layak, standar keadilan sosial dan sebagainya. ${ }^{16}$

Konstruksi maqâshid al-syarîah yang dicanangkan Jasser Auda tidak menata ulang dari awal, melainkan menata kembali, membangun dan mengembangkan maqâshid yang sudah dirumuskan ulama terdahulu. Misalnya, teori maqâshid al-syarî'ah yang digagas oleh 'Abd Mâlik al-Juwainî (w. 478H/1085 M), Abû Hâmid al-Ghazâlî (w. 505H/1111M), Fakhruddîn alRâzî (w. 606H/1209M), Sayfuddîn al-Âmidî (w. 631H/1234 M), 'Izzuddîn bin 'Abd al-Salâm (w. $660 \mathrm{H} / 1209 \mathrm{M}$ ), Syihâbuddîn al-Qarâfî (w. 684 H/1285 M), Najmuddîn al-Thûfî (w. 716 H/1316 M), Ibn Qayyim al-Jawziyyah (w. 748 H/1347 M), Tâjuddîn al-Subkî (w. 771 H/1329 M), Abû Ishâq al-Syâtibî (w. 790 H/1388 M) dan seterusnya. Teori maqâshid al-syarîah dari periode ke periode berikutnya tidaklah sama persis, tetapi mengalami perubahan, perkembangan dan tambahantambahan. Hal ini menunjukkan bahwa maqâshid al-syarîah tidak paten, permanen, melainkan bisa dikembangkan seiring dengan tuntutan dan kebutuhan zaman.

${ }^{15}$ Thaha Jâbir al-'Alwanî, Maqâshid al-Syarî'a, (Beirut: Dâr al-Hâdi, 2001), h. 25.

${ }^{16}$ Jasser Auda, Maqâshid al-Syarî’ah..., h. 36. 
Ulama usul fikih klasik mengklasifikasi maqâshid pada tiga bagian yaitu, al-maqâshid al-dharûriyyah yaitu maslahat yang menjadi kebutuhan pokok manusia di dunia dan akhirat. Apabila maslahat seperti ini tidak terpenuhi, maka akan berdampak kerusakan kehidupan di dunia dan mendapat siksa di akhirat. Maslahat seperti ini ada lima, yaitu proteksi agama, proteksi jiwa, proteksi akal, proteksi keturunan dan proteksi harta. Kedua, al-maqâshid al-hâjiyyah adalah maslahat yang dibutuhkan manusia dalam menyempurnakan maslahat pokok tersebut untuk menghilangkan kesukaran dan kesulitan. Apabila maslahat semacam ini tidak terpenuhi maka tidak sampai mengakibatkan kehidupan umat manusia menjadi rusak atau hancur, namun hanya berdampak pada kesukaran dan kesempitan. Misalnya dalam bidang ibadah diberi rukhshah untuk menjamak dan mengqasar salat, serta dibolehkan tidak puasa bagi orang musafir. Selain itu, dibolehkan bagi perempuan hamil, menyusui, dan orang sakit untuk tidak menjalani ibadah puasa. Begitu pula di lingkup muamalah dibolehkan melakukan transaksi jual beli, pesanan, sewa-menyewa dan sebagainya. Macam ketiga, al-maqâshid al-tahsîniyyah adalah maslahat yang sifatnya komplementer (pelengkap) yang dimaksudkan untuk kebaikan adat dan keanggunan akhlak mulia. Misalnya dianjurkan berpakaian yang bagus, memakan makanan yang bergizi, menjauhi makanan yang jorok, lemah lembut dan ihsan (berbuat baik) dalam berprilaku dan lain-lain. ${ }^{17}$

Sedangkan ulama kontemporer merekonstruksi dan merevitalisasi maqâshid pada tiga tingkatan, yaitu, al-maqâshid al-âmmah adalah maqâshid yang diperhatikan keberadaannya dalam seluruh babbab hukum Islam, seperti maqâshid al-dharûriyât dan al-hâjiyât sebagaimana disebutkan di atas, dan

17 'Alî Ibn Sulaimân al-Mardâwî al-Hanbalî, al-Tahbîr Syarh al-Tahrîr fî Ushûl al-Fikih, (Riyadh: Maktabah al-Rusy, 2000), Jilid VII, h. 3379. al-Bannânî, Hâsyiyah 'alâ Syarhi al-Jalâl al-Mahallî, (Beirut: Dâr al-Fikr, t.t.), Juz II, h. 280; Jalâluddîn al-Suyûthî, Syarh al-Kaukab al-Sâthi', (Kairo: Maktabah al-Îmân, 2000), Juz II, h. 411; Muhammad Ibn Bahâdir al-Zarkasyî, al-Bahru al-Muhîth fî Ushûl al-Fikih, (Kairo: Dâr al-Shafwah, 1992), Juz V, h. 208; Wahbah al-Zuhailî, al-Wajîz fî Ushûl al-Fikih, (Beirut: Dâr al-Fikr, 1999), h. 92; Hasan Ibn Muhammad Ibn Mahmûd al-'Aththâr, Hâsyiyah al-'Aththâr 'alâ Jam'i al-Jawâmi', (Beirut: Dâr alKutub al-Ilmiah, t.t.), Juz II, h. 322; Muhammad Ibn Ahmad Ibn Abdul'azîz Ibn 'Alî al-Futûhî, Syarh al-Kaukab al-Munîr, (Riyadh: Maktabah al-‘Ubaikan, 1993), Jilid IV, h. 159. juga dikembangkan dengan maqâshid baru seperti keadilan, kemudahan, kebebasan, kesetaraan, persaudaraan, toleransi, hak-hak asasi manusia dan sebagainya. ${ }^{18}$ Al-Maqâshid al-khâshshah ialah maqâshid yang terealiasasi dalam seluruh bab hukum Islam tertentu, seperti maslahat (kemanfaatan) anak dalam hukum keluarga, efek jera bagi pelaku kriminal dengan diterapkan hukuman, takzir dalam hukum pidana, larangan penimbunan dalam hukum ekonomi dan terakhir al-maqâshid al-juz'iyyah adalah maqâshid yang meliputi `illat atau hikmah di balik suatu nas atau hukum tertentu, seperti maksud mengungkap kebenaran dalam disyaratkan jumlah (satu, dua atau empat) saksi tertentu dalam kasus hukum tertentu, maksud kemudahan dalam memberi rukhshah bagi orang sakit untuk tidak berpuasa, maksud memberi makanan pada fakir miskin dalam melarang penyimpanan daging kurban selama hari 'Idul Adha. ${ }^{19}$

Letak perubahan dan perkembangan teori maqâshid al-syarîaah klasik ke maqâshid al-syarîa ah kontemporer terdapat pada titik tekan keduanya. Maqâshid al-syarî̀ah klasik lebih ditekankan pada protection (الحفظ/perlindungan) dan preservation (العصمة/penjagaan), sedang maqâshid al-syarî̀ah kontemporer lebih ditekankan pada development (التنمية/pengembangan) dan right (الحقوق/hakhak). Dengan demikian, hifzh al-dîn (proteksi agama) diperluas pemaknaannya pada menjaga, melindungi dan menghormati kebebasan beragama dan kepercayaan; hifzh al'-aql (proteksi akal) dikembangkan pemaknaannya pada optimalisasi pengembangan pola pikir, penelitian ilmiah, perjalanan menuntut ilmu, melepas mentalitas belenggu taklid dan menghargai upayaupaya dan penemuan-penemuan ilmiah; hifzh

${ }^{18}$ Yûsuf al-Qardhâwî, Dirâsah fi Fikih Maqâshid al-Syarîah Bayna al-Maqâshid al-Kulliyah wa al-Nushûsh al-Juz'iyah (Beirut: Dâr al-Syurûq, 2006), h. 69; Jamâluddîn 'Athiyah, Nahwa Taf'îl Maqâshid al-Syarîah,h. 98; 'Allâl al-Fâsî, Maqâshid al-Syarîah alIslâmiyah wa Makârimuhâ, (Riyadh: Dâr al-gharab al-Islâmî, 1993), h. 45; 'Abd al-Majî̀ al-Najjâr, Maqâshid al-Syarî'ah bi Ab'âd Jadîdah, (Beirut: Dâr al-Gharab al-Islâmî, 2008), h. 85; Muhammad Thahir Ibn 'Âsyûr, Maqâshid al-Syarî’ah al-Islâmiyah, h. 260.

19 Jasser Auda, Maqasid Shariah as Philosophy..., h. 35. Bandingkan dengan Muhammad Thahir Ibn 'Âsyûr, Maqâshid alSyarî’ah al-Islâmiyah, h. 313; Nurûddîn Ibn Mukhtâr al-Khâdimî, 'Ilmu al-Maqâshid al-Syar'iyah (Riyadh: Maktabah al-'Ubaikan, 2001), h. 74; Wahbah al-Zuhailî, Ushûl al-Fikih al-Islâmî, Juz II (Beirut: Dar al-Fikr, 2009), h. 317. 
al-'irdhi (proteksi kehormatan) dikembangkan pemaknaannya pada perlindungan harkat dan martabat manusia, dan menjaga, melindungi hakhak asasi manusia; hifzh al-mâl (proteksi harta) ditingkatkan pemaknaannya pada mengutamakan kepedulian dan kepekaan sosial, pengembangan ekonomi, meningkatkan kesejahteraan manusia, mempersempit jurang pemisah antara kaya dan miskin dan mengurangi bahkan menghilangkan perbedaan antar kelas sosial-ekonomi. ${ }^{20}$

Selain pengembangan maqâshid al-syarîah di atas, Jasser Auda mengajukan urgensi konsep pengembangan sumber daya manusia (SDM) sebagai maslahat 'âm (maslahat umum) dalam bagian maqâshid al-syarîah untuk direalisasikan melalui hukum Islam kontemporer. Setiap hukum Islam yang berdampak positif pada pengembangan SDM, semestinya dipelihara dan ditingkatkan, sebaliknya setiap hukum yang melemahkan SDM seharusnya disingkirkan dan ditolak. Realisasi maqâshid semacam ini dapat diketahui, dikontrol aspek perkembangan dan kemajuannya dari waktu ke waktu melalui data yang dirilis Human Development Index (Indeks Pembangunan Manusia) dan Human Development Targets (Target Pembangunan Manusia) yang ditetapkan oleh Persatuan Bangsa-Bangsa (PBB) atau lembaga kredibel lainnya. Pada gilirannya, perkembangan, kemajuan dan kesejahteraan umat Islam dapat diperjuangkan, diupayakan dan terus ditingkatkan dari waktu ke waktu.

\section{Pendekatan Sistem Terhadap Metodologi Hukum Islam \\ 1. Kognitif (الادراكية)}

Dalam pandangan Jasser Auda ada beberapa pemahaman yang perlu diperbaiki, direvisi, dipikirkan kembali untuk menuju validasi seluruh kognitif, yaitu:

\section{a. Memposisikan Hukum Islam sebagai Interpretasi/Hasil ljtihad Manusia}

Para fukaha (ahli fikih) memandang fikih sebagai sebuah hasil dari pemahaman, persepsi dan kognisi manusia. ${ }^{21}$ Fikih merupakan produk nalar

\footnotetext{
20 Jasser Auda, Jasser Auda, Maqâshid al-Syarî’ah.., h. 58-62.

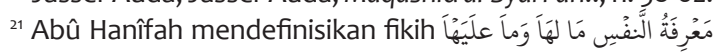
(pengetahuan seseorang tentang sesuatu yang bermanfáat dan mudarat). Muhammad Ibn 'Alî al-Syaukânî, Irsyâd al-Fuhûl
}

pikir/ijtihad 22 manusia atas nas-nas Aquran, hadis dan dalil-dalil lainnya dan karenanya kebenaran fikih bersifat relatif. Tetapi, pendapat-pendapat ulama dan hukum-hukum Islam (fikih) kerapkali dipersepsikan sebagai "hukum-hukum Allah/حكم" حun الله Alquran dan sunah al-tasyrî̉iyyah merupakan sebuah wahyu, tetapi interpretasi-interpretasi dan pemahaman-pemahaman terhadap keduanya tunduk pada penafsiran, nalar logika mufasir maupun fakih. Kendati demikian, persepsi dan interpretasi tersebut sering disematkan sebagai "perintah dan hukum Allah/امر الله وحكمة" guna mempertahankan ambisi kekuasaan, kepentingan tertentu oleh penguasa di masa silam. Selain itu, produk ijtihad sering dimasukkan dalam kategori "wahyu", padahal definisi dan validitas metodemetode ijtihad diperselisihkan di antara ulama. Auda juga menilai terdapat kesalahpahaman dalam memahami ijma'. Sejumlah ulama fikih klasik dan masa kini menganggap ijmâ' sebagai dalil qath'î yang selevel dengan nas (دليل قطي كالنص), dalil yang

ilâ Tahqîq al-Haq min 'Ilmi al-Ushûl, (Riyâdh: Dâr al-Fadhîlah, 2000), Juz I, h. 57; Imam al-Juwainî mendefinisikan fikih adalah

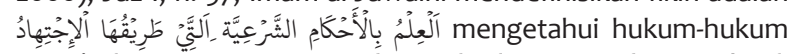
syara' dengañ cara atau jalan ijtihad. Imam al-Juwainî, alWaraqât (Beirut, Dâr al-Bâsyâiir al-Islâmiyyah, t.t), h. 82. Jumhur

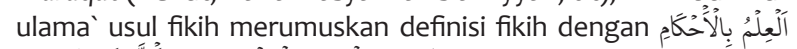

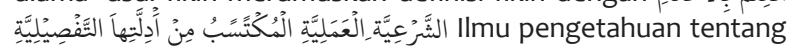
hukum-hukum syara' yang bersifat amaliyah yang diperoleh dari (pemahaman-pemahaman) terhadap dalil-dalil yang terperinci. Atau himpunan hukum-hukum syara' yang bersifat amaliyah yang diperoleh dari (pemahaman-pemahaman) terhadap dalildalil yang terperinci. Jalâluddîn al-Suyûthî, Syarh al-Kawkab alSâthi', (Kairo: Maktabah al-Iman, 2000), Juz I, h. 57; Muhammad Ibn al-Hasan al-Badakhsyî, Syarh al-Badakhsyî, (Mesir: Muhammad 'Alî Shâbih, t.th.), Juz I, h. 19; 'Abdurrahîm Ibn alHasan al-Asnawî, Nihâyah al-Sûl fî Syarhi Minhâj al-Ushûl, (Kairo: 'Âlam al-Kutub, t.th.), Juz I, h. 22. Di antara watak fikih bersifat ijtihadîyah, karenanya, KH. Sahal Mahfudh memandang perlu untuk merevitalisasi, merekontruksi dan mereformulasi produk fikih klasik yang tidak relevan dengan arus perkembangan zaman dan bertentangan dengan sosio kultural daerah tertentu. Lihat: Imam Ghazali Said dan A. Ma'ruf Asrori (peny.), Ahkâm Al-Fuqahâ' fi Muqarrarât Mu'tamarât Nahdlah Al-'Ulama' (Solusi Problema Aktual Hukum IslamKeputusan Muktamar, Munas, dan Konbes Nahdlatul Ulama 1926-1999 M), (Surabaya: Lajnah Ta`lif Wan Nasyr (LTN NU) Jawa Timur dan Diantama Lembaga Studi dan Pengembangan Pesantren, 2005), h. xvii.

22 الاجتهاد بذل الطاقة من الفقيه في تحصيل حكم شرعي ظنى Muhibbullah Ibn `Abd al-Syakûr, Musallām al-Tsubût, II, (Beirut: Dâr al-Fikr, t.th), h. 362; الاجتهاد استفراغ الفقيه الوسع لتحصيل ظن لخكم Tâjuddîn 'Abdul al-Wahhâb al-Subkî, Jam’u al-Jawâmi', (Beirut: Dâr al-Fikr, 1982), Jilid II, h. 379; 'Abdurrahmân Ibn Abi Bakar al-Suyûthî,

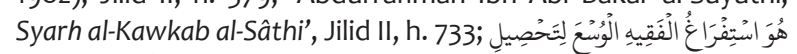

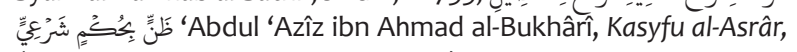
(Beirut: Dâr al-Kutub al-'Ilmiah, 1997), Jilid IV, h. 20. 
dikonstruk oleh Syâri' (دليل نصبه الشارع), bahkan

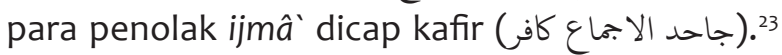
Bagi Auda, ijmâ' bukanlah sumber hukum Islam, melainkan sebuah mekanisme konsultan atau pembuatan keputusan multi partisipan. Ia menilai ijmâ' disalahgunakan oleh sejumlah ulama untuk memonopoli fatwa dan mensekatnya pada elit tertentu. Kendati demikian, prinsip-prinsip ijmâ' pada era sekarang dapat diterapkan sebagai mekanisme untuk merumuskan hukum yang bersifat kolektif, lebih-lebih didukung teknologi informasi dan komunikasi modern. ${ }^{24}$ Lebih jauh, ijmâ' juga dapat diaplikasikan dalam bentuk partisipasi masyarakat dalam memutuskan urusanurusan pemerintah. Hal ini, searah pemikiran dengan Muhammad Syahrûr, ia punya pandangan bahwa ijmâ' merupakan kesepakatan manusia modern dalam majelis-majelis perwakilan dan parlemen untuk bermusyawarah, berembuk dan berdiskusi menyangkut persoalaan umat yang terjadi. Bagi Syahrûr, kesepakatan disebut ijmâ' bila dilakukan oleh sejumlah orang-orang yang hidup di masa sekarang, bukan ijmâ' orang yang sudah meninggal, seperti ijmâ' para sahabat. Argumentasinya, karena ulama yang masih hidup yang sangat mengetahui persoalaan umat dan lebih mengetahui bagaimana cara memecahkannya ketimbang para sahabat, tabiin atau para ulama yang sudah wafat. ${ }^{25}$ Di sisi lain, sejumlah ahli fikih menganggap metode qiyâs didukung oleh wahyu. Mereka menyatakan bahwa menganalogikan antara kasus primer dan kasus sekunder adalah keputusan hukum yang

${ }^{23}$ Jumhur ulama`usul fikih mengemukakan apabila rukunrukun dan syarat-syarat ijmâ' telah terpenuhi, maka ijmâ' tersebut memiliki kekuatan hujjah yang qath'î, wajib diamalkan dan haram menyalahinya, bahkan orang yang mengingkarinya dilabeli kafir. Selain itu, permasalahan yang telah dirumuskan hukumnya melalui ijmâ', tidak boleh lagi menjadi ranah perselisihan pendapat, ketetapan hukum tersebut tidak boleh menjadi objek pembahasan mujtahid generasi sesudahnya, karena hukum yang dicetuskan melalui ijmâ' merupakan hukum syara' yang berkekuatan qath'î, tidak boleh dinasakh dan menempati posisi ketiga dalam hirarkis dalil syara' sesudah Alquran dan sunah. 'Abdul Qâdir Ibn Badrân, al-Madkhal ilâ Madzhab Imâm Ahmad Ibn Hanbal (Beirut: Mu’assasah al-Risâlah, 1981), h. 266; Muhammad Ibn Muhammad Ibn 'Abdurrahmân, Taisîr al-Wushûl ilâ Minhâj al-Ushûl min al-Ma'qûl wa al-Manqûl, (Kairo: al-Fârûq al-Hadîtsah, 2002.), Juz V, h. 74.

24 Jasser Auda, Maqasid Shariah as Philosophy..., h. 312-313.

25 Muhammad Syahrûr, Nahw Usul Jadîdah li al-Fikih al-Islâmî, (Damaskus: al-Ahâlî li ath-Thibâ'ah wa al-Nasyar alTawzî, 2000), h. 64. ditelorkan oleh syâri' itu sendiri (تشبيه فرع باُصل هو) (تشبيه الشارع). Oleh karena itu, sejumlah ulama fikih mengklaim bahwa mereka "berbicara atas nama Tuhan" terhadap kasus-kasus yang diistinbâthkan melalui metode qiyâs. ${ }^{26}$ Ini adalah bencana, mengutip Garaudy, 'ketika sekat-sekat antara firman Tuhan dan manusia telah dihapus'.

\section{b. Memisahkan Antara Wahyu dan Interpretasi}

Dalam literatur hukum Islam ada istilah al-mushawwibah (المصوبة), mereka menyatakan hukum adalah asumsi-asumsi pada diri para mujtahid ketika mengkaji, menelaah nas-nas. ${ }^{27}$ Karenanya, perlu dibedakan antara nas dengan hasil pemikiran, pemahaman atas nas, antara interpretasi-interpretasi dengan wahyu. ${ }^{28}$ Fikih, tafsir, usul fikih muncul dari pemahaman para

\footnotetext{
${ }^{26}$ Muhammad Syahrûr, Nahw Usul Jadîdah..., h. 313-314.

${ }_{27}$ Terdapat perselisihan pendapat ulama usul fikih mengenai masalah fighiyyah furû'iyah yang tidak berpijak pada dalil qath'î. Menurut kelompok pertama setiap mujtahid benar terhadap hasil ijtihadnya (كل مجتهد فيها مصيب). Pendapat ini digagas oleh Abû al-Hasan al-'Asysarî, al-Qâdhî Abû Bakar al-Baqillanî, Abû Yûsuf dan Muhammad al-Syaybanî dan Ibnu Surayj. Sedangkan kelompok kedua mengutarakan bahwa pendapat yang benar satu dan lainnya salah, tapi tidak berdampak dosa (المصيب فيها واحد) asing-masing pendapat sama-sama meniadakan ganjaran dosa pada mujtahid yang salah. Sementara itu, kelompok ketiga mengemukakan bahwa mujtahid yang benar hanya satu, yang lain salah dan menanggung beban dosa. اثم في (اثم)

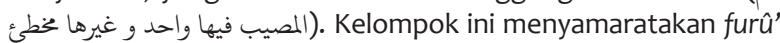
dengan ushûl. Pendapat ini diusung oleh Basyar al-Marisî, Abu Bakar al-'Ashâm, Ibnu'Ulayyah dan golongan pengingkar qiyâs, seperti golongan al-Dhâhiriyah dan al-Imâmiyah. al-Âmidî, al-Ihkâm fî Ushûl al-Ahkâm, Jilid II, 323; Abu Muhammad bin Muhammad al-Ghazali, al-Mustashfâ min 'Ilm al-Ushûl, (Beirut: Dâr al-Fikr, tt), Juz II, h. 361; Muhammad al-Khudari Bek, Ushûl al-Fikih (Beirut: Dâr al-Fikr, 1988), h. 374.

${ }^{28}$ Sebagian ulama berpendapat Alquran memiliki makna zahir dan batin, Alquran mengandung mutiara ilmu yang tidak bisa diketahui umat manusia pada umumnya. Hanya segelintir orang yang dapat menyingkap makna yang tersembunyi dibalik formal teks. Makna dibalik teks lebih luas dan lebih dalam daripada verbal teks. Senyatanya, makna zahir dan makna batin senantiasa tidak berlawanan. Al-ghazâlî dengan analisa secara ulet dan tajam mengungkapkan Alquran memiliki makna zahir yang dapat dikenal dengan uslûb bayân arab, atau melalui riwayat yang ma'stûr dari Nabi. Selain itu, Alquran juga menyimpan makna batin yang amat dalam yang hanya dapat diangkat ke permukaan melalui pendekatan al-isyârat al-bayâniah, dan bagi mereka yang mendalami aneka ragam ilmu. Meskipun demikian, memahami Alquran dengan bersandar pada akal semata tidak dapat dibenarkan, tetapi harus menggabungkan antara akal budi dan naql guna menguak kedalaman hakikat-hakikat kauniah dan nafsiyah. Abu Dardâ' mengatakan "seseorang tidak dapat dikatakan mengerti dengan sebenar-benarnya akan Alquranhingga ia menelaahnya dari berbagai aspek". Muhammad Abû Zahrah, al-Mu'jizat al-Kubrâ al-Qur'ân, (Bairut: Dâr al-Fikr, t.t. ), Juz II, h. 522-523.
} 
mujtahid terhadap nas. Lebih jauh, al-mushawwibah menyatakan diktum-diktum hukum yang beraneka macam itu dibolehkan dan kesemuanya benar. Sebab kebenaran tidaklah tunggal. Para ulama yang berada dalam barisan ini berasal dari kalangan fakih filosof, seperti Abû al-Hasan al-`Asy'arî, Abû Bakar ibn al-'Arabî, Abû Hâmid al-Ghazâlî, Ibnu Rusy dan sejumlah tokoh-tokoh mu'tazilah. al-Ghazâlî mengutarakan pandangan al-mushawwibah yang menyatakan 'hukum Tuhan (menurut ahli fikih) adalah apa yang dipersepsi oleh ahli fikih sebagai pendapat yang paling mungkin benar'. ${ }^{29}$

Pendekatan sistem pada hukum Islam dalam ranah ini mengarahkan hukum Islam sebagai sistem. Selanjutnya, implementasi cognitive nature akan menggiring pada suatu konklusi yang dekat dengan al-mushawwibah, yaitu hukum-hukum adalah hasil produk pemikiran ahli fikih yang mengandung kebenaran yang paling mungkin, sejumlah pendapat hukum yang berbeda, kesemuanya itu merupakan ekspresi-ekspresi dalam mencari kebenaran dan semua pendapat itu adalah benar.

Lebih lanjut, Auda memperjelas titik bedatemu syariah, fikih, 'urf dan qânûn untuk memisahkan aspek wahyu dari fikih. Sehingga posisi fikih bergeser dari 'pengetahun ilahi' menuju ranah 'pengetahuan manusia terhadap wahyu'. Karenanya, menjadi jelas garis beda antara fikih dan syariah. Selanjutnya, perlu diperjelas pula tipe-tipe perbuatan Nabi Saw yang sesuai dengan maqâshidnya. Dalam konteks ini, jika disorot dengan pendekatan sistem, maka satu bagian sunah digeser ke luar lingkaran wahyu, dan satu bagian lagi berada di bagian batas lingkaran. Pembatasan ini dengan memperhatikan multiperan Nabi Saw dalam merespon permasalahan Arab pada saat itu. Dengan demikian, sunah Nabi Saw secara garis besar dapat diklasifikasi pada tiga kategori, yaitu: a) Sunah yang termasuk dalam kategori tasyrî’, imam al-Qarâfî mengistilahkan dengan 'al-tasharruf bi altablîgh', b) Sunah yang dihasilkan dari ijtihad Nabi Saw, dengan tujuan-tujuan tertentu. Sunah dalam katogeri ini harus dipahami dan diimplementasikan dengan memperhatikan konteks asal sewaktu ia disabdakan, dan c) Sunah yang berada dalam lingkup kehidupan manusia biasa sehari-hari. ${ }^{30}$

\footnotetext{
${ }^{29}$ Jasser Auda, Maqâshid al-Syarî'ah..., h. 315.

30 al-Badakhsyî, Syarh al-Badakhsyî, Juz II, h. 198; 'Alî Ibn
}

Ketiga kategori sunah ini memiliki konsekwensi tersendiri dalam sumber hukum Islam. Sunah pada bagian (a) dan (b) bisa dijadikan sebagai rujukan dalam istinbâth hukum Islam dengan tetap memperhatikan konteksnya. Sementara sunah pada bagian (c) tidak dapat dijadikan rujukan dalam perumusan hukum Islam karena ia muncul dari sifat basyariah Nabi saw. ${ }^{31}$

\section{Holistik (شمولية التشريع)}

Dalam pandangan Jasser Audah sekurangkurangnya terdapat dua hal urgen yang mesti diperhatikan, dipikirkan ulang dalam bagian ini, yaitu:

\section{a. Ketidakpastian (ظنية) Dalil-dalil Individual}

Pada umumnya ulama fikih menggunakan pendekatan reduksionis-atomistik dalam kerangka pola metode istinbâth-nya. Pendekatan atomistik acap kali memakai satu nas dalam merumuskan sejumlah kasus, tanpa melacak nas-nas lain yang terkait. Pendekatan semacam ini mendapat kritik tajam dari sebagian ulama karena terperangkap pada zhanniyah (ketidakpastian) yang melekat padanya, berhadap-hadapan dengan qath'iyyah (kepastian). Fakhruddîn al-Râzî memaparkan sekurang-kurangnya ada sembilan argumen zhanniyah (ketidakpastian) yang berdalil dengan nas tunggal. ${ }^{32}$ Jasser Audah menambahkan ada

\footnotetext{
'Adam Mûsa, al-Jâlis al-Shâlih al-Nâf', h. 249; al-Ashfahânî, Bayân al-Mukhtashar Syarh Mukhtashar Ibn al-Hâjib, Juz I, h. 480; al-Bannânî, Hâsyiyah 'alâ Syarhi al-Jalâl al-Mahallî, Juz I, h. 97; al-'Aththâr, Hâsyiyah al-'Aththâr 'alâ Jam'i al-Jawâmi', Juz II, h. 129; al-Subkî, Raf'u al-Hâjib 'an Mukhtashar Ibn al-Hâjib, Juz II, h. 102; Jalâluddîn al-Suyûthî, Syarh al-Kawkab al-Sâthi', Juz II, h. 9; Ibn 'Alî al-Futûhî, Syarh al-Kawkab al-Munîr, Jilid II, h. 178; al-Jaizawî, Hâsyiyah Mukhtashar al-Muntahâ al-Ushûlî, Juz II, h. 291; Ahmad Zaidan, Marâqî al-Su'ûd ilâ Marâqî al-Su'ûd, h. 257; al-Baidhâwî, Nihâyah al-Sûl fî Syarhi Minhâj al-Ushûl, Juz III, h. 17. ${ }^{31}$ Jasser Auda, Maqâshid al-Syarî'ah...,h. 316-317.

32 1. Besar kemungkinan nas tunggal dapat dibatasi oleh kondisi-kondisi tertentu, tanpa sepengetahuan kita; 2. Besar kemungkinan nas tunggal itu metaforis, sedang makna hakikatnya tidak dimaksudkan; 3. Referensi kita dalam memahami nas adalah ahli bahasa arab yang mungkin salah; 4. Grammar bahasa arab yang sampai kepada kita melalui syair-syair arab kuno melalui riwayat-riwayat tunggal (riwayat âhâd). Riwayat-riwayat âhâd ini tidak bersifat pasti dan penggubah syair-syair itu sendiri dapat melakukan salah tata bahasanya; 5. Ada kemungkinan satu kata atau lebih dalam nash tunggal memiliki multimakna; 6 . Ada kemungkinan satu kata atau lebih pada nas tunggal telah mengalami perubahan, seiring berlalunya waktu, dengan bentuk yang mengubah makna asal; 7. Ada kemungkinan nas tungal punya makna
} 
tiga kemungkinan lagi, selain apa yang telah dirumuskan al-Râzî, yaitu: a) ada kemungkinan nas tunggal menyiratkan suatu makna yang kontradiktif dengan nas-nas tunggal lainnya. Hal ini terjadi dalam sebagian besar nas dan bisa dilacak dalam bahasan tersendiri, b) ada banyak kemungkinan kesalahan dalam penyampaian hadis-hadis âhâd, yang mayoritas hadis Nabi diriwayatkan secara âhâd, c) ada banyak kemungkinan interpretasi atas nas tunggal apa pun, yang bisa memengaruhi kita dalam memahami makna dan dalâlah-nya. ${ }^{33}$

\section{b. Keterbatasan Kausalitas (السببية) dalam Teori Tradisional dan Modernis}

Ulama usul fikih menitikberatkan pentingnya implementasi dalil holistik (dalil kullî). Al-Juwainî misalnya, memperhitungkan untuk mengacu pada dalil-dalil kullî hukum Islam sebagai dalil hukum, dan dinilai metode yang sah, yang dinamakan analogi holistik (qiyâs kullî). ${ }^{34}$ Al-Syâthibî menilai usul fikih harus dibangun atas universalitas syariah (kulliyâh al-syarîah ). Dia juga memberikan prioritas terhadap kaidah-kaidah holistik/ universal (al-qawâ'id al-kulliyyah) di atas hukumhukum tunggal dan parsial (âhâd al-juz'iyyah). Argumentasinya, karena hukum-hukum tunggal atau parsial dimaksudkan untuk mendukung kaidah-kaidah holistik yang merupakan maqâshid hukum yang mesti dipelihara. ${ }^{35}$

Para modernis muslim menilai terdapat sejumlah kelemahan dalam pendekatan-pendekatan parsial dan individual dalam istinbâth hukum Islam. Begitu pula, ulama kontemporer berupaya memperbaiki kekurangan metode parsial dalam ide maqâshid syarî̀ah . Diantaranya, Ibnu 'Âsyûr memprioritaskan maqâshid sosial di atas maqâshid individual, Rasyîd Ridhâ memasukkan reformasi dan hak-hak asasi masyarakat dalam teori maqâshid-nya. Thaha al-

yang tersembuyi (khafî), yang tidak dapat kita pahami; 8. Ada kemungkinan hukum yang kita istinbathkan telah dinasakh tanpa sepengetahuan kita; 9. Ada kemungkinan hukum yang diistinbathkan dari nas tunggal kontradiksi dengan nalar logika, antara makna dan teks dengan realitas rasional tidak bisa diterima. Jasser Auda, Maqashid al-Syari'ah..., h. 318-319.

33 Jasser Auda, Maqashid al-Syari'ah.., h. 319.

34 al-Juwainî, al-Burhân fi Ushûl al-Fikih, (Mesir: al-Wafâ’, 1997), Jilid II, h. 590.

${ }^{35}$ Abû Ishâq al-Syâthibî, al-Muwâfaqât fî Ushûl al-Syarî’ah, Jilid II, h. 61.
'Alwânî mengusulkan maqâshid pengembangan peradaban di muka bumi dalam teori maqâshid-nya. Demikian halnya, Yûsuf al-Qardhâwî menggagas maqâshid universal berbasis Alquran yang bertujuan keluarga dan bangsa yang baik. ${ }^{36}$

Dalam konteks ini, modernisme Islam membangun pola pikir yang bercorak holistik, yang dikenal dengan tafsir tematik. Diantara pakar yang intens dalam isu ini adalah Hasan Turabî, pengarang al-Tafsîr al-Tawhîdî. Menurutnya, pendekatan penyatuan atau holistik memerlukan sejumlah metode pada beragam level. Pada level bahasa menuntut korelasi yang integral bahasa Alquran dengan bahasa pesan-pesan Alquran yang digunakan pada waktu turunnya wahyu. Di sisi lain, pada level pengetahuan manusia memerlukan pendekatan holistik terhadap dunia ghaib (tidak terlihat) maupun dunia nyata dengan seluruh komponen dan aturan yang mempengaruhinya. Pada level topik memerlukan hubungan dengan tema-tema tanpa memperhatikan urutan ayatayat Alquran, di samping diimplementasikannya dalam kehidupan sehari-hari. Dengan demikian, pendekatan ini mesti melibatkan semua orang tanpa memperhatikan dimensi ruang dan waktu mereka. Pendekatan ini juga menuntut integrasi hukum dengan moralitas dan spiritualitas dalam satu pendekatan yang holistik. ${ }^{37}$ Kendati demikian, dalam melakukan istinbath hukum Islam dari nas Alquran dan sunah perlu memperhatikan beberapa hal, yaitu: 1) pengistinbâth mesti memiliki pengetahuan yang mempuni tentang kaidah-kaidah bahasa. 2) Memperhatikan sabab al-nuzûl atau sabab alwurûd baik yang mikro maupun yang makro. 3) Menggabungkan nas yang dikaji dengan yang lain, menghubungkan ayat dengan ayat, hadis dengan hadis, ayat dengan hadis dan hadis dengan ayat. 4) Mengawinkan nas-nas syara' dengan maqâshid al-syarîah . 5) Mengaitkan nas dan kasus yang dikaji dengan ilmu-ilmu sosial, humaniora atau sains. 6) Mengaitkan nas dengan realita.

Menurut Jasser Auda prinsip holistik dalam filsafat sistem dapat digunakan dalam usulan pembaruan kontemporer, bukan hanya dalam persoalaan fikih, melainkan juga dalam ilmu kalam. Jabarannya, dalil penciptaan (dalil ikhtirâ')

\footnotetext{
${ }^{36}$ Jasser Auda, Maqâshid al-Syarî'ah..., h. 321.

37 Jasser Auda, Maqâshid al-Syarî'ah..., h. 321.
} 
hendaknya disandarkan pada 'kemustahilan suatu perbuatan tanpa suatu maksud' daripada 'kemustahilan perbuatan tanpa suatu sebab'. Sementara itu, dalil pemeliharan atau penjagaan (dalil al-ri'âyah) seyogyanya disandarkan pada 'keseimbangan dan keramahan manusia dalam ekosistem dan subsistem' daripada argumentargumen klasik berupa klaim kebenaran. Begitu pula, dalil eksistensi Tuhan (dalil al-wujûd) sebaiknya disandarkan pada desain alam semesta yang sistematik dan integratif daripada menyandarkannya pada argumen kosmologi klasik tentang transisi pertama. ${ }^{38}$

\section{Keterbukaan dan Pembaruan (الانفتاح والتجدد) (الذاتي}

Suatu sistem harus bersifat terbuka agar tetap eksis dan tetap hidup. Dalam ranah ini, ada dua hal yang perlu ditinjau kembali guna merevitalisasi hukum Islam, yaitu: pertama, perubahan hukum-hukum fikih karena perubahan cara pandang seorang fakih atau perubahan peradaban. Hal ini sebagai sebuah mekanisme keterbukaan dalam sistem hukum Islam. kedua, memperkaya dan membuka diri pada dunia filsafat sebagai sebuah mekanisme peremajaan dalam sistem hukum Islam.

\section{a. Perubahan Hukum Karena Perubahan Kultur Kognitif}

Diantara sumber hukum Islam yang diakui oleh ulama usul fikih adalah 'urf, 'Urf merupakan dasar dalam teori hukum Islam. Islam acap kali berkaitan dengan sosio-kultural masyarakat dan bahkan peradaban suatu umat. ${ }^{39}$ Salah satu kaidah usul fikih

\footnotetext{
${ }^{38}$ Jasser Auda, Maqâshid al-Syarî’ah, h..., 323.

39 Menurut imam al-Qarâfî (684 H; Tokoh fikih Mâliki) seorang mujtahid dalam menetapkan hukum, terlebih dahulu harus meneliti adat kebiasaan yang tersebar luas di masyarakat, sehingga hukum yang ditetapkan itu tidak menghilangkan atau berpunggungan dengan kemashlahatan. Dalam kaitan ini Ibnu al-Qayyim berujar bahwa fakih (pakar fikih) yang benar adalah seseorang yang mampu mengelaborasikan penetapan hukum dan realita. Dalam mencetuskan hukum ia tidak saja berjibaku dengan nash, tetapi juga melihat realitas sosial supaya hukum yang hendak digulirkan bisa mewadahi kemashlahatan masyarakat. Karenanya, seringkali ia menurunkan taraf yang ideal pada tatanan realita. Inilah yang mendasari Ibnu Qayyim menetapkan keniscayaan perubahan fatwa dikarenakan perubahan zaman, tempat, 'urf dan kondisi masyarakat. Ibnu Qayyim al-Jawziyah, A'lâm al-Muwaqqi'în 'an Rabbil’âlamîn, Jilid. IV, h. 139.
}

المعروف yang dirumuskan ulama Hanafiyah adalah عرفا كالمشروط نصا (aturan yang dikenali menurut 'urf sama dengan aturan yang disyaratkan berdasarkan nas). ${ }^{40}$ Berbagai mazhab mengimplementasikan kaidah ini ketika tidak ada nas yang menjelaskan status hukumnya. Dengan berpijak pada 'urf maka sejumlah adat, 'urf dan tradisi suatu masyarakat yang berbeda dengan adat kebiasaan Arab dapat diakomodasi. Di mana para ulama fikih membangun dan merumuskan sejumlah hukum Islam dengan berpijak pada 'urf, yang dapat kita temukan dalam lembaran-lembaran kitab klasik. Diantara contoh-contoh persoalan hukum yang merujuk pada 'urf adalah nilai/jumlah mahar (maskawin), mata uang yang dipakai sebagai alat tukar dalam transaksi jual beli, menutupi kepala bagi laki-laki atau tidak menutupinya. Selain itu, jenis-jenis makanan, barang dalam zakat fitrah dan zakat mal masih ditentukan oleh bahan makanan dan barang abad ke-7M, yang dipaparkan dalam hadis terkait, yaitu kurma, kismis dan gandum. Begitu pula, sejumlah hukum yang terkait dengan politik seperti batas-batas negeri Islam (dâr al-Islâm) dan negeri peperangan (dâr al-harbi). Contoh lainnya, pembayaran diyat pembunuhan tidak disengaja dibebankan pada 'âqilah (keluarga si pembunuh), sekalipun sosio-kultural di suatu daerah telah berubah. Padahal wajah dunia dan pandangan dunia dari segi kehidupan sosial sudah berubah dalam persoalaan di atas.

Dengan memperhatikan watak kognitif hukum Islam maka bisa diketengahkan bahwa 'urf adalah apa yang dipandang sebagai 'urf oleh fakih, sesuai

${ }^{40}$ Dengan mendasarkan pada sumber 'urf, ulama' fikih merumuskan beberapa kaidah fikih yang bisa dibuat sandaran dalam menetapkan hukum Islam. Kaidah-kaidah itu adalah:

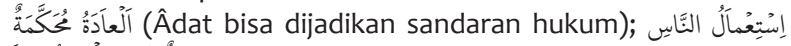

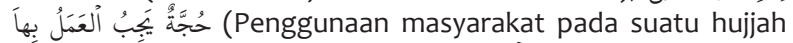

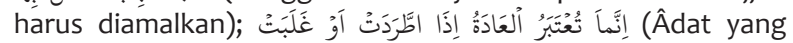
diperhitungkan untuk dibuat sandaran hukum apabila ia di-

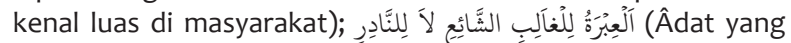
diperhitungkan yang sudah berlaku luas bukan yang jarang

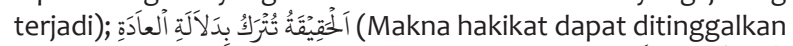

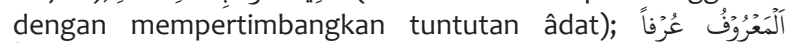
كالَْشَرُوْرِط شَرْطاً (Sesuatu yang sudah diketahui secara umum

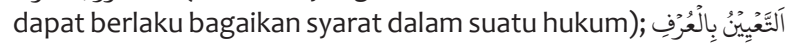

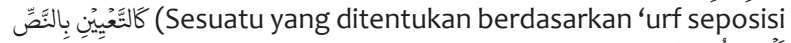

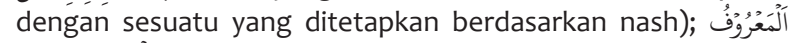

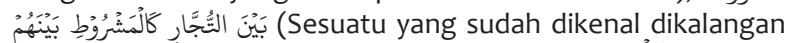

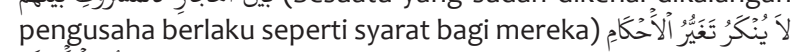
(Perubahan hukum sebuah keniscayaan karena perubahan zaman). 
dengan pandangan dunianya, dengan syarat tidak berbenturan dengan prinsip-prisip dasar maqâshid syarîah.$^{41}$ Karenanya, pandangan dunia (worldview) fakih dalam kaitannya dengan metode urf cukup mewarnai terhadap istinbâth hukum yang ditetapkan. Selain itu berfungsi sebagai perluasan metode 'urf dalam mengakomodasi perubahan-perubahan adat tradisi arab. Karena itu, maka Jasser Auda menawarkan kaidah baru terkait dengan perubahan hukum yang berbunyi (suatu hukum dapat berubah disebabkan perubahan kultur kognitif atau worldview -fakih-). ${ }^{42}$

Menurut Jasser Auda sebaiknya seseorang fakih dalam dalam mengistinbâth hukum Islam tidak cukup merujuk pada Alquran dan sunah, tapi ia mesti memiliki wawasan yang luas mengenai masalah yang hendak diijtihadi. Maka perlu memasukkan pandangan dunia seorang fakih dalam sistem hukum Islam. Kemudian worldview dikombinasikan dengan Alquran dan sunah dalam memproduksi hukum Islam. Akan tetapi, worldview (pandangan dunia fakih) harus benar, tidak didasarkan pada praduga semata, melainkan berlandaskan basis ilmiah. Sebab, seorang fakih bila tidak memiliki pandangan dunia yang kompeten maka berpotensi menelorkan keputusan hukum yang tidak akurat. Pandangan semacam ini merupakan perluasan atas fikih realitas (fikih wâqi') yang dikemukakan oleh Ibn al-Qayyim dan dinilai sebagai syarat yang diperhitungkan dalam berijtihad.

Oleh sebab itu, dengan memasukkan worldview

${ }^{41}$ Dalam konteks ini, Ibnu 'Âbidîn mendiskripsikan secara anggun dalam satu risâlah yang bertajuk "nasyru al"urfi". la mengemukakan bahwa kebanyakan hukum berbeda dilatarbelakangi perbedaan zaman karena perubahan tradisi masyarakat, ada suatu darurat (yang mendesak) atau kerusakan moral dan perilaku masyarakatnya. Pada gilirannya, jika suatu hukum tetap dipertahankan sebagaimana semula, maka mesti berefek pada kesukaran dan kemudaratan bagi manusia dan berbenturan dengan kaidah-kaidah sharîah yang berdimensi keringanan dan kemudahan serta menepis kemudaratan dan kehancuran. Seringkali ulama Hanafiyah menyikapi keanekaan pendapat itu dengan ungkapan "ini perbedaan masa dan tempat, bukan perbedaan hujjah dan dalil”. Ibnu "Âbidîn, Majmû'ah Rasâ'il Ibni ‘Âbidîn, (t.tp: t.np, t.t), Juz II, h. 125. Ibnu 'Âbidîn, Raddu al-Mukhtâr 'alâ Durri al-Mukhtâr, (Beirut: Dâr alKutub al-Ilmiyah. 2003), Juz IX, h. 178; Muhammad Ibn Abî Sahl al-Sarkhasî, al-Mabsûd, (Beirut: Dâr al-Ma'rifah, tt.), Juz VIII, h. 178; Ibnu al-Himâm al-Hanafî, Syarh Fath al-Qadîr, (Beirut: Dâr al-Kutub al-Ilmiyah, 2003), Juz V, h. 405.

42 Jasser Auda, Maqâshid al-Syarî’ah..., h. 324. berkonsekwensi positif pada dua hal dalam hukum Islam yaitu: a. dengan memperhatihan perubahanperubahan pandangan dunia bagi seorang fakih akan meminimalisir pemahaman literalis (الفهم الحرفي) dalam istinbâth hukum Islam. Istinbâth hukum secara literal rentan menghasilkan hukum Islam yang kaku. ${ }^{43}$ b. dampak positif kedua dengan memasukkan pandangan dunia yang kompeten dalam persyaratan ijitihad adalah dapat membuka sistem hukum Islam terhadap kemajuan dalam ilmu-ilmu alam dan sosial. ${ }^{44}$

\section{b. Pembaruan Hukum Islam dengan Keterbukaan pada Filsafat}

Dalam pandangan Jasser Auda hukum Islam bisa menggapai pembaruan diri dengan terbuka terhadap komponen lain dari pandangan dunia yang kompeten seorang fakih, yakni filsafat. Karena usul fikih sejatinya adalah filsafat hukum Islam. karenanya, usul fikih mesti menjaga keterbukaan dengan filsafat, yang secara umum berkembang seiring evolusi pengetahuan manusia.

Akan tetapi, sejarah hukum Islam mencatat bahwa mayoritas ulama dari pelbagai aliran mazhab menolak baik secara keras maupun ringan untuk menggunakan filsafat dalam mengembangkan metodologi hukum Islam atau pengetahuan Islam secara umum. Pada umumnya, dalam penolakannya, mereka menghadirkan sebagian teori-teori filsafat Yunani yang bertentangan dengan akidah umat Islam yang sudah dikenal luas. Sejumlah ulama menghukumi haram belajar dan mengajarkan filsafat karenamenurut mereka-dibangun atas prinsip-prinsip metafisika non-Islami. Di antara pembesar ulama dari beragam mazhab yang berfatwa demikian adalah Ibn `Aqîl (w. 512 H/1119 M), al-Nawawî (w. 675 H/1277 M), al-Suyûthi (w. 910 H/1505 M), al-Qushairî (w. $510 \mathrm{H} / 1127$ M), Ibn Raslân (w. $1003 \mathrm{H} / 1595 \mathrm{M}$ ), al-Syarbinî (w. 986 H/1579 M) dan Ibn al-Shalah (w. 643 H/1246 M). Fatwa Ibn al-Shalah yang banyak dirujuk terkait topik ini dalam literatur hukum Islam. Kritik kerasnya terhadap filsafat diungkapkan bahwa filsafat

والجمود على المنقولات أبدا ضلال في الدين وجهل بمقاصد علماء المسلمين 43 . Ibn al-Qayyim, A'lâm al-Muwaqqi'în... Juz, III, h. 99.

44 Penjelasan lengkapnya bisa dibaca, Jasser Auda, Maqâshid al-Syarî'ah..., h. 329-331. 
merupakan 'asal kedunguan dan percampuran' dan pedang adalah cara yang mesti dilakukan untuk bersentuhan dengan para guru filsafat. Dampak reaksi keras ini adalah sikap pencampakan, penolakan terhadap filsafat di banyak dunia Islam. Ibn Rusy (w. 584 H/1189 M) seorang fakih-filosof ketika bersebrangan pendapat dengan fatwa pengharaman filsafat maka karya-karyanya dibakar dan dimusnahkan. ${ }^{45}$

Kendati mayoritas ulama menolak dan mengkritik filsafat Yunani, metode-metode non-Islam kemudian mereka berupaya merumuskan ide-ide alternatif, dari sudut pandang mereka sendiri, seperti Ibn Taimiyah dan Ibn Hazm, tetapi nampaknya alGhazâlî menginternalisasi logika Yunani sebagai cara berpikir dalam teori-teori yang digagasnya. al-Ghazâlî berada dalam dua sayap terkait filsafat Yunani, satu sisi ia mengkritik keras filsafat Yunani karena 'paganisme'nya (وثنية) dan mencap murtad pada filosuf muslim. Di sisi lain, ia menerima alat logika Aristoteles (Organon, bahasa Yunani), bahkan menilainya sebagai sebuah 'pengantar wajib bagi seluruh disiplin ilmu', yang tanpanya 'seorang cendekiawan tidak mendapat predikat kredibel dalam cabang pengetahuan apa pun'. Ide cemerlang al-Ghazâlî adalah menggabungkan deduksi silogistik dalam metodologi qiyâs. Untuk sistematisasi tahqîq al-manâth, al-Ghazâlî mengimplementasikan himpunan silogisme verifikatif terhadap situasi pertama. Selanjutnya, al-Ghazâlî memanfaatkan silogisme hipotesis sebagai 'premis minor' dalam dua proposisi sebagai 'illat itu sendiri, sehingga dapat memindahkan hukum dari 'premis mayor' pada 'premis minor'. Misalnya, setiap khamr adalah memabukkan. Setiap yang memabukkan adalah haram. Maka khamr adalah haram. ${ }^{46}$ Generasi cendekiawan berikutnya seperti al-Âmidî ( $w$. $633 \mathrm{H} / 1236 \mathrm{M}$ ), al-Subkî (w. 755 H/1374 M) dan sejumlah ulama yang berhaluan mazhab Asy'arî dan Syâfî̂ memilih satu kata dengan al-Ghazâlî dalam membedakan antara 'alat-alat abstrak' yang bisa ditransfer dari non muslim, dan pemikiran-pemikiran dan konsep-konsep yang tidak boleh diambil.

Bersebrangan arus pemikiran dengan fukaha (ahli fikih) sebelumnya, Ibn Rusyd bersikap sangat terbuka terhadap pengetahuan manusia.

\footnotetext{
45 Jasser Auda, Maqâshid al-Syarî’ah..., h. 331-333.
}

${ }^{46}$ Jasser Auda, Maqâshid al-Syarî’ah..., h. 335-337.
Pandangannya didasarkan pada seruan Alquran terhadap umat Islam untuk berpikir dan berenung mengenai ciptaan Allah Swt. Karenanya, setiap penalaran filosofis yang dibangun atas logika yang benar mesti diterima, tanpa menghiraukan agama pencetusnya. Ide cerdasnya menawarkan solusi bila terjadi kontradiksi antara akal dan nas adalah melakukan reinterpretasi (ta'wîl) atas nas sekadar yang dibolehkan bahasa, sehingga selaras dengan nalar akal. Ibn Rush mengkritik keras terhadap al-Ghazâlî dan fukaha yang tergesagesa menuding pada filosof sebagai murtad/ zindiq, tanpa menelusuri lebih mendalam posisi mereka. ${ }^{47}$ Oleh karena itu, menurut Jasser Auda kita perlu mengimplementasikan keterbukaan Ibn Rusyd terhadap seluruh bahasan filsafat dan memperluas keterbukaan ini pada pembaruan teori-teori usul fikih agar sistem hukum Islam bisa responsif-progresif dan bermuatan humanis.

\section{Hierarki Saling Berkaitan (التركيبية المرمية)}

Fitur ini mengacu pada teori kategorisasi dalam ilmu kognisi. Kategorisasi merupakan proses mengaitkan entitas-entitas yang terpisah dan berserakan menuju ruang yang berkarekteristik multidimensi. Kategorisasi merupakan aktivitas kognitif yang sangat fundamental, dimana manusia memahami informasi yang diterima, membuat generalisasi dan prediksi, memberi mana, dan menilai berbagai item dan ide. Menurut Jasser Auda berdasarkan sains kognitif terdapat dua alternatif metode kategorisasi, yaitu kemiripan fitur (feature similarity) dan konsep mental (mental concepts). ${ }^{48}$

Kategorisasi pertama berupaya mengungkap kesamaan dan perbedaan alami di antara entitasentitas dengan cara diukur berdasarkan seberapa banyak relevansi dan perbedaan antara keduanya dalam hubungannya dengan karakteristik tertentu yang ditetapkan terlebih dahulu. Sedangkan kategorisasi kedua menentukan kategori berbasis kontep mental, ketimbang persamaan fitur. Konsep mental merupakan teori pokok dalam persepsi pembuat kategorisasi, yang mencakup kombinasi sabab-musabab kompleks yang diungkapkan dalam kontruk terstruktur. Sebuah

\footnotetext{
47 Jasser Auda, Maqâshid al-Syarî'ah..., h. 339.

48 Jasser Auda, Maqâshid al-Syarî'ah..., h. 99-100.
} 
konsep bukan sekadar fitur, melainkan sebuah kriteria multidimensi, yang bisa memunculkan sejumlah kategorisasi simultan untuk sejumlah entitas yang sama. Kategorisasi yang digunakan Jasser Auda adalah kategorisasi berbasis konsep yang akan diimplementasikan pada usul fikih, beragam mazhab dan metode. Klasifikasi tidak terbatas pada struktur hierarki, melainkan hingga mengalisis hubungan-hubungan yang saling berkelindan antara hasil subkonsep-subkonsep. ${ }^{49}$

Fitur hierarki kalau diimplementasikan dan dibuat analisis pada maqâshid al-syarî̀ah maka menciptakan semua elemen menjadi satu-kesatuan yang terintegrasi dan terkoneksi. Al-Maqâshid al-‘âmmah (maqâshid umum), al-maqâshid alkhâshshah (maqâshid spesifik), al-maqâshid alkulliyah (maqâshid universal), al-maqâshid aljuz'iyah (maqâshid parsial) saling berkelindan menyatu dalam muatan hukum Islamsesuai dengan yang diperlukan. Jika maqâshid tradisional bernuansa partikular, spesifik, terbatas pada alkulliyah al-khams, maka fitur hierarki dengan penelaahan atas sejumlah nas-nas Alquran dan sunah mencetuskan nilai-nilai universal sebagai maqâshid al-syarîaah .

\section{Multidimensional (تعدد الأبعاد)}

Pada bagian ini dalam rangka membawa sistem hukum Islam melesat menuju multidimensional maka perlu merekonstruksi, merevitalisasi dan mereformulasi pemahaman pada dua konsep dasar usul fikih, yaitu qath'î (kepastian) dan ta'ârudh (kontradiksi).

\section{a. Spektrum Qath'î (Kepastian)}

Bahasan yang tidak luput dalam torehan karya-karya ulama klasik adalah masalah qath'î (pasti) dan zhannî (belum pasti).50 Pada biasanya,

\footnotetext{
49 Jasser Auda, Maqâshid al-Syarî'ah..., h. 101-102.

${ }^{50}$ Ragam hukum jika ditelisik dari aspek apakah 'illat (الِعِلَّة) yang terkandung dapat dijangkau akal logika maupun tidak, terbagi pada dua macam, yaitu: hukum-hukum ta'abbudîl ghair al-ma'qûl al-ma'nâ (dogmatis/irasional) dan hukumhukum al-ma'qûl al-ma'nâ (rasional). Hukum-hukum ta'abbudî adalah hukum-hukum yang 'illat-nya hanya diketahui Allah Swt., seperti jumlah rakaat shalat, ukuran nishab harta wajib zakat, ukuran had-had (hukuman-hukuman), kaffârat dan bagian-bagian tertentu dalam harta waris. Sedang hukumhukum al-ma'qûl al-ma'nâ adalah hukum-hukum yang 'illat-nya dapat dijangkau akal logika melalui nash-nash dan dalil-dalil
}

keduanya didudukkan secara dikotomi yang sangat kental dalam berbagai metodologi dan mazhab. Sudut pandang semacam ini berpotensi pada sikap absolutisme yang memercikkan beberapa problem. Menurut pengamatan Jasser Auda, ulama klasik mengklafisikasi qath'î pada tiga bentuk, yaitu qath'î al-dalâlah (implikasi linguistik secara pasti), qath'î al-tsubût (pasti periwayatannya) dan al-qath'î almanthiqî (implikasi logis). ${ }^{51}$ Bagi Jasser Auda, konsep qath'î dan zhannî bukanlah ketentuan final, makanya ia dapat diotak-atik dan perlu ditinjau kembali. Berikut analisis tajam Jasser Audah atas qath'î dan zhannî dan implikasi-implikasinya. ${ }^{22}$

1. Nas-nas yang jelas secara linguistik dalam Alquran dan sunah diklaim nas-nas qath'î al-dalâlah.

Terkait dengan segmen ini, ada beberapa contoh hadis yang dihadirkan oleh Jasser Auda, yaitu:

a) Nabi Saw mendengar dua orang bertikai terkait persewaan lahan pertanian. Lalu Nabi bersabda:

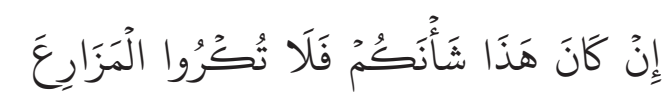
"Jika ini menjadi sikapmu, maka janganlah kamu menyewakan tanah”. (HR. Abû Dâud)

b) Nabi Saw. bersabda:

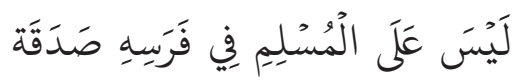
"Seorang muslim tidak dikenai kewajiban zakat untuk kudanya" (HR. al-Bukhârî)

lain, seperti keharaman khamr, riba dan sebagainya. 'Abdul alWahhâb Khallâf, 'Ilmu Ushûl al-Fikih, h. 62. Nash qath'îal-dalâlah adalah lafazd-lafazd yang menunjukkan pemahaman tertentu, tidak dimungkinkan ta'wîl dan tidak bisa dipahami makna lain darinya. Sementara nash zdannî al-dalâlah adalah lafazdlafazd yang memuat pengertian lebih dari satu, dimungkinkan untuk dita`wîlkan dan bisa dialihkan dari suatu makna pada makna lain. 'Abdul al-Wahhâb Khallâf, 'Ilmu Ushûl al-Fikih, h. 35; Wahbah al-Zuhailî, Ushûl al-Fikih al-Islâmî, Juz I, h. 424.

${ }^{51}$ Ulama` usul fikih sepakat bahwa seluruh nash Alquran dipandang di segi wurûd-nya (datangnya) berkualitas qath'î (pastibenar). Dalampengertian, kami mempercayai secara pasti dengan sepenuh hati bahwa seluruh nash Alquranditurunkan dari Allah Swt. kepada Rasulullah Saw. untuk disampaikan pada umat manusia, tanpa sedikit pun perubahan dan penggantian. Akan tetapi, apabila dilihat dari segi dalâlah Alquranterhadap hukum-hukum yang dikandungnya terpetakan pada dua bagian, yaitu nash qath'î al-dalâlah dan nash zdannî al-dalâlah. Wahbah al-Zuhailî, al-Wajîz fî Ushûl al-Fikih (Beirut: Dâr al-Fikr, 1999), h. 32.

52 Jasser Auda, Maqâshid al-Syarî'ah..., h. 342. 
c) Nabi Saw. bersabda:

$$
\text { وإن في النفس الدية مائة من الإبل }
$$

"... dan diyat pembunuhan pada satu jiwa adalah seratus ekor unta..." (HR. anNaisaburi)

Mantûq (pemahaman tersirat) hadis (a) secara dalâlah linguistik (al-dalâlah allughawiyah) menghasilkan suatu 'kepastian' hukum haram menyewakan lahan pertanian. Sedang pemahaman tersirat secara dalâlah linguistik pada hadis (b) melahirkan hukum ketidakwajiban zakat kuda. Hadis (c) menghasilkan hukum, diyat pembunuhan adalah 100 ekor unta. Menurut penilaian Jasser Auda, metode penggalian hukum dari nas-nas yang jelas, yang kemudian dinilai qath'î, semestinya harus mempertimbangkan fakta bahwa mungkin ada nas-nas lain yang menunjukkan suatu status hukum yang berbeda. Akan tetapi, ulama bersikokoh bahwa faktor lain tersebut harus berada dalam satu level/derajat 'kepastian' yang setara.

Bagi Auda, semestinya dalam memahami nas tidak terpaku pada pemahaman secara dalâlah linguistik, melainkan melihat konteks tertentu yang menyebabkan lahirnya suatu nas, seperti konteks ekonomi, politik, lingkungan dan sebagainya. Dengan model penggalian hukum semacam ini membuat nas tidak kehilangan spirit dan konteksnya. Karenanya, melalui pola istinbâth semacam itu, maka hadis pertama bisa dipahami bahwa Nabi saw melarang para sahabat dalam menyewakan lahan pertaniannya, karena pertengkaran itu terjadi. Larangan itu berarti hanya bisa diterapkan ketika kemungkinan terjadi perseteruan. Dari hadis kedua bisa dipahami bahwa bila konteks ekonomi berubah, di mana kuda memiliki nilai ekonomi yang signifikan, maka harus dikenakan zakat. Dan hadis terakhir melahirkan suatu pemahaman bahwa ukuranukuran diyat dan 100 ekor unta terkait dengan konteks sosial Arab pada waktu itu. ${ }^{53}$

2. Kepastian (qath'î) terkait autentitas historis atau qath'î al-tsubût terbagi

53 Jasser Auda, Maqâshid al-Syarî’ah...,h. 344. dalam berbagai tingkatan, mutawâtir, masyhûr dan âhâd. Keseluruhan Alquran dan sebagian kecil hadis masuk dalam kategori mutawâtir. Selain itu, mayoritas ulama menilai bahwa hadis âhâd yang diterima umat Islam' (خبر) sebagai qath'î.

Diantara contoh pada bagian ini, yaitu hujjah berupa hadis-hadis âhâd yang digunakan Ibn Taimiyah sebagai dalil untuk menetapkan dasar-dasar agama. Ibn Taimiyah memasukkan beberapa hal dalam lingkup akidah, seperti keyakinan pada sifat-sifat Allah Swt, bersikap sabar dan menerima atas penetapan pemimpin dari suku Quraish, mengusap sepatu sewaktu berwudu, lagu-lagu sufi dinilai bidah dan sebagainya. Klaim-klaim semacam ini berpotensi besar dalam memercikkan api konflik yang berdarah-darah dan bahkan peperangan, sebagaimana yang telah terjadi berkali-kali dalam sejarah Islam. Sebab itu, sejarah kelam umat Islam agar tidak terulang kembali, kita mesti mengembangkan budaya toleransi dan hidup penuh kerukunan dengan tidak memusatkan perhatian pada perbedaanperbedaan, sekaligus memisahkan antara hadis-hadis âhâd yang bersifat zhannî dengan masalah-masalah akidah yang qath'î.54

3. Al-Qath'î al-manthiqî (kejelasan, kepastian logis), al-luzûm al-mathiqî atau al-yaqîn almanthiqî. Term ini dalam metodologi hukum Islam erat kaitannya dengan bahasan qiyâs, yang dibangun atas kesamaan 'illat. Sebagian ulama sunni tidak menganggap adanya 'kepastian, kejelasan' dalam 'illat hukum. Menurut al-Ghazâlî ada enam sebab yang menjadikan 'illat bersifat kemungkinan (ihtimâl) dan bukan qath'î. 55

54 Jasser Auda, Maqâshid al-Syarî'ah...,h. 346.

55 1. Kita mengasumsikan adanya sebab tertentu pada suatu hukum, padahal tidak punya sebab, menurut Allah Swt; 2. Hukum tersebut memiliki sebab, menurut Allah Swt., tapi kita keliru memahaminya; 3. Hukum tersebut memiliki lebih dari satu sebab, menurut Allah Swt., tetapi kita melakukan kesalahan dalam membatasinya pada satu sebab; 4. Hukum tersebut memiliki satu sebab, menurut Allah Swt., tetapi kita melakukan kekeliruan dengan menambahkan sebabsebab yang kurang tepat; 5. Kita mungkin sukses dalam menetapkan suatu sebab hukum, tetapi kita bisa keliru dalam mempertimbangkan hukum tersebut pada hukum lain dalam analogi qiyâs, yang tidak sesuai menurut Allah Swt; 6. Kita melakukan kesalahan dengan menyandarkan sebab 


\section{b. Melerai Kontradiksi Antar Dalil-dalil Melalui Multidimensional}

Dalam ilmu usul fikih kontradiksi antar dalildalil dikenal dengan istilah ta'ârudh al-'adillah (تعارض الأدلة). Pada dasarnya, tidak bakal terjadi kontraksi antara dalil-dalil yang sederajat, pertentangan itu hanya berdasarkan persepsi diri mujtahid. Secara zahir tampak kontradiksi, tapi secara substansi tidak. ${ }^{56}$ Kontradiksi itu terjadi bisa saja dikarenakan seorang fakih kurang mengetahui informasi terkait waktu, kondisi atau tempat yang menyertai sebuah nas. Faktor-faktor ini punya efek besar dalam mewarnai pemahaman dan pengaplikasiannya.

Apabila terjadi kontradiksi antara dalil-dalil maka ada enam metode yang ditetapkan oleh para ulama usul fikih, yaitu al-jam'u (menggabungkan), al-nasakh (menghapus/membatalkan), al-tarjîh (mengunggulkan), at-tawaqquf (ditangguhkan), al-tasâquth (sama-sama digugurkan) dan altakhyîr (pilihan). Dalam penerapan metode ini terjadi perbedaan; ulama Hanafi mengedepankan penerapan al-nasakh sebelum metode lainnya, kemudian disusul metode al-tarjîh. ${ }^{57}$ Sedangkan seluruh mazhab lainnya memprioritaskan aljam'u ketika tejadi kontradiksi dalil-dalil. Hal ini berdasarkan suatu ketentuan 'mengamalkan suatu nas lebih utama daripada mengabaikannya' (اعمال

tertentu pada suatu hukum dalam gambaran kita semata, tanpa mencurahkan segenap daya pikir/ijtihad. Jasser Auda, Maqâshid al-Syarî'ah..., h. 347-348.

${ }^{56}$ Menurut imam al-Syâthibî perbenturan dalil-dalil syara' hanya terbatas pada kulit saja. Menurutnya, pertentangan itu bisa terjadi dalam dalil yang qath'î dan bisa juga dalil zdannî, selama kedua dalil itu satu derajat. Bila pertentangan itu terjadi antara dalil yang tidak sederajat maka dalil yang lebih kuat diamalkan. Seperti al-qur'ân bertentangan dengan hadith âhâd maka dalil yang dijadikan pedoman adalah al-qur'ân, karena dari segi periwayatannya al-qur'ân bersifat qath'î sedangkan hadith âhâd bersifat zdannî. al-Syâthibî, al-Muwâfaqat fî Ushûl al-Ahkâm, Jilid II, h. 63. Seirama dengan pandangan ini, Wahbah al-Zuhaili berpendapat pertentangan antara kedua dalil itu hanya dalam penilaian mujtahid sesuai dengan ketajaman analisa dan kekuatan nalar pikirnya, bukan pertentangan yang bersifat subtansial, karena imposimble Shâri' mengundangkan dua dalil yang berpunggungan pada satu kasus dan satu waktu. Wahbah al-Zuhailî, Ushûl al-Fikih al-Islâmî, Jilid II, h. 452.

57 al-Kamâl bin al-Hammâm, al-Taqrîr wa al-Tahbîr, Jilid III (Bairut: Dâr al-Kutub al-'Ilmiah, 1983), h. 3, 'Abdus al-Syakûr, Musallam al-Tsubût, Jilid II, h. 392-395, Nidhâmuddîn al-Ansharî, Fawâtif al-Rahamût, Jilid II, h. 392-395, Muhammad al-Khudarî Bek, Ushûl al-Fikih, h. 358-359, Abdul Wahhâb Khallâf, 'Ilmu Ushûl al-Fikih, h. 229-232.
. mayoritas ulama tidak memberikan prioritas aljam'u, malahan yang banyak digunakan adalah metode al-nasakh dan al-tarjîh. Oleh sebab itu, dijumpai sejumlah dalil yang terabaikan tanpa argumentasi yang kuat dikarenakan para fakih gagal paham dalam memahami seluruh dalil dalam kerangka kognitif yang integral.59

Dalam pandangan Jasser Auda, pembatalan atas beberapa dalil merupakan suatu bentuk kesewang-wenangan. Misalnya, suatu riwayat diabaikan dan dianggap lemah ketika salah seorang perawinya tidak menyebutkan 'waktu kejadiannya (تاريخ الحادثة)', kata-kata yang dinisbatkan pada Nabi Saw. lebih metaforis dari lainnya, atau perawinya seorang wanita ketika bertentangan dengan hadis yang diriwatkan laki-laki maka hadis yang perawinya laki-laki diutamakan. Bagi Jasser Auda, hal yang urgen adalah memanfaatkan metode al-jam'u dengan konsep multidimensional dalam mengatasi kelemahan-kelemahan tersebut. Sebab, pembatalan pada sejumlah ayat dan hadis atas nama al-mansukh dan al-tarjîh menyebabkan stagnasi, jumud, kekakuan dalam hukum Islam.

Apabila direnungkan secara mendalam pada sejumlah hadis yang tampak bertentangan tersebut, terkadang disebabkan perbedaan situasi dan kondisi, seperti kondisi perang dan damai, kemiskinan dan kekayaan, kehidupan kota dan pedalaman, musim panas dan musim dingin, sakit dan sehat, atau muda dan tua dan sebagainya. Karena itu, untuk memahami Alquran secara baik dan benar butuh pada pengetahuan atas asbâb al-nuzûl dan asbâb al-wurûd sehingga tidak keliru dalam mengenali maksud dari perintah dan larangan yang terkandung di dalamnya. Selain itu, minimnya pengetahuan atas konteks nas mengakibatkan kurangnya nilai fleksibilitas nas. Misalnya, menerapkan dalil-dalil yang terjadi dalam konteks damai pada dalil-dalil yang terjadi dalam konteks perang. Sehingga membuat seorang fakih melakukan kesalahan dalam memahaminya. ${ }^{60}$

Selain metode di atas, Jasser Auda mengkonsepsi metode multidimensional dikombinasi-

\footnotetext{
${ }^{58}$ Abdul Wahhâb Khallâf, 'Ilmu Ushûl al-Fikih, h. 229-231.

59 Jasser Auda, Maqâshid al-Syarî’ah..., h. 351-353.

60 Jasser Auda, Maqâshid al-Syarî'ah..., h. 353-354.
} 
kan dengan pendekatan maqâshid untuk melerai dilema dalil-dalil yang berkontradiksi. Karena terkadang dalil-dalil tampak bertentangan bila hanya dilihat dari satu sudut padang, misalnya perang dan damai, perintah dan larangan, lakilaki dan perempuan dan sebagainya. Bila kita hanya terpaku pada satu dimensi maka kita sulit menemukan solusi dalam mengkompromikan dalil-dalil yang ber-ta'ârudh. Sebaliknya, jika kita membuka cakrawala pemikiran dengan memasukkan satu dimensi lagi, yaitu dimensi maqâshid, maka bisa saja dalil-dalil yang nampak kontradiksi itu saling mendukung mencapai suatu maksud tertentu, tetapi dalam konteks yang berbeda-beda. Dengan demikian, kedua dalil atau beberapa dalil sama-sama dapat diamalkan dalam bingkai maqâshid. Pendekatan multidimensional juga menuntut lebih dari maqâshid syarî̀ah, selagi bisa digunakan. ${ }^{61}$

\section{Beroreintasi Maqâshid (المقاصدية)}

Maqâshid merupakan fitur pokok pendekatan sistem yang berfungsi sebagai pengikat diantara seluruh sistem dasar lainnya, seperti kognisi, holistik, openness, heirarki, saling terikat dan multidimensional. Pendekatan sistem berbasis maqâshid diproyeksikan dalam berkontribusi terhadap pengembangan usul fikih sehingga dapat dilakukan istinbâth hukum Islam yang humanisresponsif-progresif.

Berdasarkan pengamatan Jasser Auda, ia menemukan bahwa metodologi hukum Islam klasik lebih menekankan pada kajian indikasi lafazh (الدلالات اللفظية), tidak meneluri indikasi bahasa terhadap maqâshid (الالاتة) (الدلالة اللغوية المقاصدية). Para ulama fikih klasik—baik ulama Hanafiyah maupun Mutakallimin-memberikan prioritas kajiannya pada kajian bahasa. Pola pembacaan ini menerapkan makna literal terhadap nasnas. Dalam tataran ini, Ibn 'Âsyûr menyatakan sebagian besar usul fikih tidak menaruh perhatian mendalam pada hikmah dan maqâshid al-syarîah . Akan tetapi, bahasan-bahasannya banyak berkutat mengenai istinbâth ahkâm (hukum-hukum) dari nas-nas Syâri'. Upaya ini sekadar pena'wîlanpena'wîlan terhadap kandungan-kandungan

61 Jasser Auda, Maqâshid al-Syarî’ah..., h. 356. makna nas, baik nas berdiri sendiri, bergandengan atau terpisah-pisah. Kesemuanya itu dilakukan secara tercerabut dari hikmah dan maqâshid alsyarîah umum maupun khusus dalam hukumhukum yang digulirkan. Ulama fikih membatasi bahasan-bahasannya tertuju pada lafaz-lafaz syarîah. ${ }^{62}$

Problem pendekatan literalis dan minimnya pemanfaatan dalâlah maqshad (indikasi berbasis maqâshid) atau spirit nas merupakan polemik umum dalam metodologi terkait dengan teksteks undang-undang, bahkan dalam aliran filsafat hukum kontemporer. Aliran filsafat Jerman, utamanya Jhering dan aliran filsafat Perancis, tokoh utamanya Geny mengkampanyekan dalam memaksimalkan maqâshid (المقاصدية), bahkan menyerukan rekonstruksi hukum berdasarkan maqâshid demi merealisasikan maslahat dan keadilan. Jhering menyeru pergantian dari metode 'mekanis kausalitas' menuju metode maqâshid. Ke arah sana, Geni menyeru untuk mewujudkan suatu metode yang memberi signifikansi lebih besar pada maqâshid tasyrî̀/perundang-undangan yang diistibâthkan dari teks yang dengannya bisa mengarahkan interpretasi penafsir undangundang. Namun, sayangnya ajakan-ajakan progresif ini belum membuahkan perubahanperubahan mendasar dalam metodologi umum filsafat undang-udang positif saat ini. Dengan demikian, pemanfaatan maqâshid merupakan filsafat hukum dan tasyrî'/perundang-undangan yang sangat dibutuhkan. ${ }^{63}$

Dalam pemikiran Jasser Auda bahwa sistem dalâlah linguistik (الدلالات اللغوية) dalam usul figh bisa merealisasikan maqâshid (مقاصدية) dengan beberapa usulan berikut ini:

a. Dalâlah al-maqshad (دلالة المقصد) harus ditambahkan pada macam-macam dalâlah lingustik terhadap nas-nas (لدلالات اللغوية) (للنصوص). Namun, prioritasnya tidak dapat ditetapkan secara rigit, melainkan dalâlah al-maqshad tunduk pada kondisi yang mengitarinya dan urgensi 'maksud' itu sendiri

b. Kemungkinan takhshîsh, ta'wîl dan nasakh merupakan tiga kriteria yang membedakan

\footnotetext{
${ }^{62}$ Jasser Auda, Maqâshid al-Syarî'ah..., h. 363.

${ }^{63}$ Jasser Auda, Maqâshid al-Syarî'ah..., h. 364-365.
} 
dengan macam-macam 'ibârat, yaitu muhkam, nas, zhâhir dan mufassar. Pada ranah ini, maqâshid dalam dibuat dasar dalam takhshîsh dan ta`wîl. Suatu 'ibârat bisa ditakhshîsh dan dita`wîl dengan maqâshid itu sendiri atau 'ibârat tersebut menakhshîsh atau mena`wîl 'ibârat lain berdasarkan maqâshid.

c. Tujuan 'ibârat harus menentukan validitas mafhûm mukhâlafah-nya. Berbeda dengan metode klasik yang mengaitkan kehujjahan mafhûm mukhâlafah apabila suatu 'illat dapat mencakup dua hukum yang bertentangan dalam satu waktu. Dan jika makna-makna mafhûm mukhâlafah ditunjukkan oleh nasnas lain maka setiap dalâlah-dalâlah yang bertentangan itu diperhitungkan dalam area maqâshid umum maupun khusus.

d. Ungkapan Alquran atau sunah mengenai maqâshid, yang biasanya berbentuk umum atau muthlaq harus diberlakukan umum, tidak boleh ditakhshîsh atau dibatasi dengan nas-nas khusus. Sebaliknya, nas-nas khusus tidak boleh diabaikan demi memenuhi kepentingan nas-nas umum dan muthlaq. Dengan demikian, setiap 'ibârat diberikan peran dalam implikasinya terhadap hukum dalam bingkai maqâshid umum maupun khusus.

e. Korelasi antara 'ibârat-'ibârat mushlaq, muqayyad (dibatasi) dan yang berkaitan dengan hukum itu sendiri yang memantik perselisihan pendapat di kalangan ulama, hubungan itu harus didasarkan dari aspek kesesuaiannya pada maqâshid, bukan dilandaskan pada kaidah linguistik atau logika umum. ${ }^{64}$

\section{Penutup}

Berdasarkan paparan di atas, maka bisa disimpulkan bahwa Jasser Auda merupakan tokoh muslim kontemporer yang berpikir ekstra untuk berijtihad dalam menganalisa metodologi hukum Islam dengan teori sistem berbasis maqâshid al-syarîah, ini dimaksudkan guna menghadirkan hukum Islam yang memuat prinsip-prinsip keadilan, kesetaraan, kebebasan, toleransi, kasih sayang,

\footnotetext{
${ }^{64}$ Jasser Auda, Maqâshid al-Syarî’ah..., h. 366-367.
}

kemajuan berperadaban, persaudaraan, hak-hak asasi manusia, kemanusiaan, dan pemeliharaan lingkungan. Bagi Jasser Auda, memasukkan pengembangan sumber daya manusia dalam maslahat umum sebagai bagian dari maqâshid al-syarîah sangat penting. Hal itu mungkin dilakukan dengan mengacu pada laporan dari indeks pengembangan manusia. Jasser Auda memanfaatkan enam fitur teori atau filsafat sistem, yaitu kognitif, holistik, keterbukaan, hierarki, multidimensional, dan berorientasi maqâshid sebagai alat analisis pada teori-teori metodologi hukum Islam. Melalui pendekatan ini, setiap teori-teori klasik yang terdapat kebuntuan ketika diaplikasikan pada nas-nas syara', tidak mendapatkan titik temu, dapat diurai dan dilerai berbasis pada maqâshid, sehingga semua teori dapat diintegrasikan dan diinterkoneksikan dalam membaca sejumlah nas, serta secara cermat memerhatikan realita.

Oleh sebab itu, setiap hukum Islam yang berdampak positif pada pengembangan sumber daya manusia, semestinya dipelihara dan ditingkatkan, sebaliknya setiap hukum yang melemahkan sumber daya manusia, seharusnya disingkirkan dan ditolak. Dengan langkah semacam ini, diharapkan umat Islam dari waktu ke waktu semakin berkualitas dalam segala aspek kehidupan; pendidikan, ekonomi, politik, budaya dan hukum, sehingga Islam benar-benar dicitrakan dan diketahui masyarakat dunia sebagai agama yang unggul dan berperadaban maju.

\section{Pustaka Acuan}

'Abdurrahmân, Muhammad Ibn Muhammad Ibn, Taisîr al-Wushûl ilâ Minhâj al-Ushûl min alMa'qûl wa al-Manqûl, Juz V, Kairo: al-Fârûq al-Hadîtsah, 2002.

‘Âbidîn, Ibnu, Raddu al-Mukhtâr 'alâ Durri alMukhtâr, Juz IX, Beirut: Dâr al-Kutub alIlmiyah, 2003.

'Âsyûr, Muhammad Thâhir Ibn, Maqâshid alSyarîah al-Islâmiyah, Cet. 2. Yordan: Dâr alNafa is, 2001.

'Athiyyah, Jamâluddîn, Nahwa Taf'îl Maqâshid alSyarîah, Damaskus: Dâr al-Fikr, 2001.

Abdullah, M. Amin, Epistemologi Keilmuan Kalam dan fikih Dalam Merespon Perubahan di Era 
Negara-Bangsa dan Globalisasi; Pemikiran Filsafat Keilmuan Agama IslamJasser Auda. Jurnal alSyir'ah, Vol. XIV No. 2 Juli - Desember 2012.

Alwânî, Thaha Jâbir al-, Maqâshid al-Syarîah, Beirut: Dâr al-Hadi, 2001.

Âmidî al-, al-Ihkâm fî Ushûl al-Ahkâm, Juz I, Beirut: Dâr al-Fikr, 1996.

Anshârî, 'Abdul al-'Alî Muhammad bin Nidhâmuddîn al-, Kitâb Fawâtih al-Rahamût, Jld II, Beirut: Dâr al-Fikr, t.t.

Arfan, Abbas, "Maqâshid al-Syarî̀ah sebagai sumber hukum Islam; Analisis terhadap pemikiran Jasser Auda", Jurnal al-Manahij, Vol VII, No. 02, Tahun 2013.

Asybahânî, Mahmûd bin 'Abdurrahmân al-, Bayân al-Muhktashar Syarh Mukhtashar Ibn al-Hâjib fî Ushûl al-Fikih, Jld II, Mesir: Dâr al-Salam, 2004.

Auda, Jasser, Maqâshid al-Syarî̀ah kafalsafah littasyrî’ al-Islâmî ru'yah mandhûmiyah, terj. ‘Abdul Lathîf al-Khayyath, Jordania: al-Ma’had al-Aly li al-Fikr al-Islâmî, 2012.

Badrân, 'Abdul Qâdir ibn, al-Madkhal ilâ Mazhab Imâm Ahmad Ibn Hanbal, Beirut: Mu`assasah al-Risâlah, 1981.

Bannânî al-, Hâsyiyah 'alâ Syarhi al-Jalâl al-Mahallî, Juz II, Beirut: Dâr al-Fikr, t.t.

Bukhârî, 'Abdul 'Azîz bin Ahmad al-, Kasyfu al-Asrâr, Jld IV, Beirut: Dâr al-Kutub al-'Ilmiah, 1997.

Fasa, Muhammad Iqbal, "Reformasi Pemahaman Teori Maqâshid Syarî'ah; Analisis Pendekatan Sistem Jasser Auda", Jurnal Hunafa: Jurnal Studia Islamika, Vol. 13, No. 2 Desember 2016,

Fâsî, 'Allâl al-, Maqâshid al-Syarî̀ah al-Islâmiyah wa Makârimuhâ, Riyadh: Dâr al-gharab alIslâmî, 1993.

Ghazâlî, Abû Muhammad bin Muhammad al-, alMustashfâ min 'Ilmi al-Ushûl, II, Beirut: Dâr al-Fikr, tt.

Hammâm, al-Kamâl ibn al-, al-Taqrîr wa al-Tahbîr, Jld III, Bairut: Dâr al-Kutub al-'Ilmiah, 1983.

Hanafî, Ibnu al-Himâm al-, Syarh Fath al-Qadîr, Juz V, Beirut: Dâr al-Kutub al-Ilmiyah, 2003.

Hanbalî, 'Alî Ibn Sulaimân al-Mardâwî al-, al-Tahbîr Syarh al-Tahrîr fî Ushûl al-Fikih, Jld VII, Riyadh: Maktabah al-Rusy, 2000.

Jawziyah, Ibn Qayyim al-, A'lâm al-Muwaqqi'în 'an Rabbil’âlamîn, Jld III, Beirut: Dâr al-Fikr, 1977. Juwainî al-, al-Burhân fî Ushûl al-Fikih, Mesir: alWafâ', 1997, Jilid II
Khallâf, Abdul Wahhâb, 'Ilmu Ushûl al-Fikih, Kairo: Dâr al-'Ilmu, 1978.

Khudharî Bek, Muhammad al-, Ushûl al-Fikih, Beirut: Dâr al-Fikr, 1988.

Najjâr, 'Abd al-Majîd al-, Maqâshid al-Syarî̀ah bi Ab'âd Jadîdah, Beirut: Dâr al-Gharab al-Islâmî, 2008.

Prihantoro, Syukur, "Maqâshid al-Syarî’ah dalam Pandangan Jasser Auda; Sebuah Upaya Rekontruksi Hukum Islam Melalui Pendekatan Sistem", Jurnal at-Tafkir, Vol. X, No. 1, Juni 2017

Qardhâwî, Yûsuf al-, Dirâsah fi Fikih Maqâshid al-Syarî̀ah Bayna al-Maqâshid al-Kulliyah wa al-Nushûsh al-Juz iyah, Beirut: Dâr al-Syurûq, 2006.

, Kaifa Nata'âmal ma'a al-Qur'ân al-'adhîm, Kairo: Dâr al-Syurûq, 1999.

Said, Imam Ghazali dan A. Ma'ruf Asrori (peny.), Ahkâm al-Fukaha fî Muqarrarât Mu'tamarât Nahdlah Al-'Ulama (Solusi Problema Aktual Hukum IslamKeputusan Muktamar, Munas, dan Konbes Nahdatul Ulama 1926-1999 M), Surabaya: Lajnah Ta'lif Wan Nasyr, 2005.

Sarkhasî, Muhammad Ibn Abî Sahl al-, al-Mabsûd, Juz VIII, Beirut: Dâr al-Ma'rifah, tt.,

Subkî al-, Jam'u al-Jawâmi fî Ushûl al-Fikih, Beirut: Dâr al-Kutub al-Ilmiah, 2003.

Supriadi, Akhmad, Sistem Sebagai Filsafat; Tawaran Baru Jasser Auda Bagi Pengembangan Hukum Islam Kontemporer", Jurnal Studi Agama dan Masyarakat, Vol 13, No 2, Desember 2017

Suyûthî, Jalâluddîn al-, Syarh al-Kaukab al-Sâthi', Juz II, Kairo: Maktabah al-Iman, 2000.

Syahrûr, Muhammad. Nahw Usul Jadîdah li al-Fikih al-Islâmî. Damaskus: al-Ahâlî li ath-Thibâ'ah wa al-Nasyar al-Tawzî, 2000.

Syâthibî, Abû Ishâq al-, al-Muwâfaqât fî Ushûl alSyarîa ah, Jld II, Mesir: al-Maktabah al-Tijâriyah al-Kubrâ, tt.

Zahrah, Muhammad Abû, al-Mu'jizat al-Kubrâ alQur'ân, Juz II, Bairut, Dâr al-Fikr, t.t.

Zarkasyî, Muhammad Ibn Bahâdir al-, al-Bahru al-Muhîth fî Ushûl al-Fikih, Juz V, Kairo: Dâr al-Shafwah, 1992.

Zuhailî, Wahbah al-, al-Wajîz fî Ushûl al-Fikih, Beirut: Dâr al-Fikr, 1999. , Ushûl al-Fikih al-Islâmî, Jld II. Beirut: Dâr al-Fikr, 2009. 